\title{
Targeted in vivo expression of the cyclin-dependent kinase inhibitor p21 halts hepatocyte cell-cycle progression, postnatal liver development, and regeneration
}

\author{
Hua Wu, ${ }^{1}$ Michael Wade, ${ }^{1,3}$ Leonard Krall,, ${ }^{1}$ Joe Grisham, ${ }^{2}$ Yue Xiong, ${ }^{1}$ and Terry Van Dyke ${ }^{1,4}$ \\ ${ }^{1}$ Department of Biochemistry and Biophysics and ${ }^{2}$ Department of Pathology, University of North Carolina at Chapel Hill, \\ Chapel Hill, North Carolina 27599 USA
}

The CDK inhibitor p21 (WAF-1/CIP-1/SDI-1) has been implicated in DNA damage-induced p53-mediated $\mathrm{G}_{1}$ arrest, as well as in physiological processes, such as cell differentiation and senescence, that do not involve p53 function. To determine the impact of p21 on normal development and cell-cycle regulation in vivo, we have generated transgenic mice that abundantly express $\mathbf{p} 21$ specifically in hepatocytes. During postnatal liver development, when transgenic p21 protein becomes detectable, hepatocyte proliferation is inhibited dramatically. This disturbance causes a reduction in the overall number of adult hepatocytes, resulting in aberrant tissue organization, runted liver and body growth, and increased mortality. The transgenic p21 protein is associated with most, if not all, of the cyclin D1-CDK4 in liver but not significantly with other cyclin/CDK proteins, indicating the importance of cyclin D1-CDK4 function in normal liver development. The appearance of large polyploid nuclei in some hepatocytes indicates that 221 may also cause arrest during the $G_{2}$ phase of the cell cycle. Significantly, partial hepatectomy failed to stimulate hepatocytes to proliferate in $\mathbf{p} 21$ transgenic animals. These results provide the first in vivo evidence that appropriate 21 levels are critical in normal development and further implicate $\mathrm{p} 21$ in the control of multiple cell-cycle phases.

[Key Words: Cell cycle; liver development; liver regeneration; $\mathrm{CDK}$ inhibitor; p21; growth arrest; trangenic mice; cell specificity]

Received October 20, 1995; revised version accepted December 1, 1995.

Control of cellular proliferation requires a balance between positive and negative regulatory pathways. Several experimental approaches suggest that such balance is achieved, in part, by regulating the activity of the cyclin-dependent kinases (CDKs) that provide the primary control of eukaryotic cell-cycle progression. In mammalian cells, both CDKs and cyclins constitute multiple gene families. Each CDK controls the transition through different points of the cell cycle through specific associations with the various cyclins. For example, CDKs associated with the $\mathrm{D}$ - and E-type cyclins appear to control the rate of passage through the $G_{1}$ phase of the cell cycle, and perturbations in the levels of these proteins can lead to the loss of normal $G_{1}$ control (Sherr 1994; Hunter and Pines 1994). In addition to cyclin activation, CDK activity is also regulated by subunit phosphorylation, both stimulatory and inhibitory (Solomon 1994; Morgan 1995).

\footnotetext{
${ }^{3}$ Present address: CATO Research, Durham, North Carolina 27713-2280 USA.

${ }^{4}$ Corresponding author.
}

Recent studies have revealed that CDK activity can also be negatively regulated by several $\mathrm{CDK}$ inhibitors (Sherr and Roberts 1995). At least seven CDK inhibitors have been identified, and on the basis of homology, these currently can be classified into two prototype groups denoted by the first members discovered-p21 and p16 (Sherr and Roberts 1995). The p16 family currently includes four related members: p16 ${ }^{\text {Ink } 4 a}$ (also known as MTS1, CDK4I; Serrano et al. 1993; Kamb et al. 1994; Nobori et al. 1994), p15 ${ }^{\text {Ink4b }}$ (also known as MTS2 and p14; Guan et al. 1994; Hannon and Beach 1994; Kamb et al. 1994), $\mathrm{pl} 8^{\text {Ink4C }}$ (Guan et al. 1994), and $\mathrm{p} 19^{\text {Ink4d }}$ (Hirai et al. 1995; Ming et al. 1995; Guan et al. 1996). The proteins of this family bind specifically to CDK4 and CDK6, preventing the association of the CDKs with cyclin D (Hirai et al. 1995; Guan et al. 1996). The genes that encode two members-p16 and p15-are mutated in certain human tumors (Kamb et al. 1994; Nobori et al. 1994; Sherr and Roberts 1995), implicating these CDK inhibitors as tumor suppressors.

The proteins of the p21 family are structurally and 
functionally distinct from those of the p16 family and currently include three members: $\mathrm{p} 21$ (also known variously as WAF1, SDI1, Cip 1, CAP 20, Picl, and CDKN1; El-Deiry et al. 1993; Harper et al. 1993; Xiong et al. 1993a; Noda et al. 1994); p27 ${ }^{\text {Kipl }}$ (Polyak et al. 1994; Toyoshima and Hunter 1994), and p57 ${ }^{\mathrm{Kip} 2}$ (Lee et al. 1995; Matsuoka et al. 1995). These proteins can complex with and thereby regulate the activity of a wide range of cyclin and CDK enzymes (Sherr and Roberts 1995). In addition, p21 binds proliferating cell nuclear antigen (PCNA), a processivity factor for DNA polymerase $\delta$, and inhibits PCNA-dependent DNA replication in vitro (Flores-Rozas et al. 1994; Li et al. 1994; Waga et al. 1994; Luo et al. 1995; Chen et al. 1995). Binding of p21 or p27 to $\mathrm{CDK}$ has also been shown to block activating phosphorylation of CDK by CDK-activating kinase (CAK) (Kato et al. 1994; Aprelikova et al. 1995). Therefore, p21 could potentially regulate cell-cycle progression through multiple distinct molecular mechanisms.

Expression of the $p 21$ gene is induced by a wide range of cell growth regulatory signals, including DNA damage from a p53-dependent mechanism (El-Deiry et al. 1993; Xiong et al. 1993a; Dulic et al. 1994), cellular senescence (Noda et al. 1994), and the antiproliferative transforming growth factor $\beta$ (TGF- $\beta$; Elbendary et al. 1994; Datto et al. 1995; Li et al. 1995). Examination of the expression of p21 transcripts in cultured cells and in mice has shown a correlation between $\mathrm{p} 21$ expression and the withdrawal of cells from the division cycle during differentiation of a number of cell types (Jiang et al. 1994; Michieli et al. 1994; Steinman et al. 1994; Guo et al. 1995; Halevy et al. 1995; Missero et al. 1995; Parker et al. 1995). Such correlation raises the possibility of a potential role for $\mathrm{p} 21$ in normal cell differentiation. Mice homozygous for a null mutation in the $p 21$ gene, however, developed normally and did not demonstrate a predisposition to tumorigenesis, suggesting that $\mathrm{p} 21$ is not required for normal differentiation (Deng et al. 1995). The interpretation of the knockout experiments, however, was complicated by the possibility that $\mathrm{p} 21$ function in $\mathrm{p} 21$-null mice may be compensated by other CDK inhibitors. Additionally, it was not possible to assess the pathophysiological consequence of altered p21 levels in p21-null animals. In vitro studies have demonstrated that relative levels of p21 may be critical in determining the threshold kinase activity of various cyclin-CDK enzymes (Zhang et al. 1994; Harper et al. 1995), suggesting that appropriate levels of p21 may be critical in normal cell division and animal development.

The ability to manipulate the levels of transgene expression in specific tissues in vivo provides an alternative strategy to assess the functional roles of $\mathrm{p} 21$ in the developing animal. The liver provides an excellent and well-characterized experimental system for studying the cell-cycle and cellular proliferation and differentiation in vivo, in part because of the ability to analyze cell cycle regulatory molecules during liver regeneration in response to partial hepatectomy (Lu et al. 1992; Loyer et al. 1994). In this study we have used a liver-specific promoter (Yan et al. 1990) to direct selective expression of murine p21 to hepatocytes. Using this strategy we have effectively created a dominant mutant phenotype for $\mathrm{p} 21$ that facilitates a functional analysis of the cell cycle within an otherwise genetically normal animal.

\section{Results}

\section{Targeted expression of $p 21$ in liver}

To elicit deregulated expression of the $\mathrm{p} 21 \mathrm{CDK}$ inhibitor within the liver of mice, we used transcriptional regulatory signals from the liver-specific gene that encodes transthyretin (TTR), a serum thyroid hormone carrier produced in hepatocytes (Yan et al. 1990). We showed previously that the first exon and intron and a partial second exon of a TTR minigene consisting of $3 \mathrm{~kb}$ upstream of the RNA start site is expressed consistently to very high levels (up to 1.5 -fold of the endogenous TTR mRNA) in the livers of transgenic mice (Yan et al. 1990). The mouse p21 cDNA was cloned after PCR amplification from a mouse fibroblast cDNA library, confirmed by sequence analysis, and inserted into the second exon of the TTR minigene (Fig. 1A). The $3^{\prime}$-untranslated sequences were replaced with a small fragment from the SV40 early region that carries the 3 ' end RNA processing signals. Five founder mice were produced with this transgene (Table 1, TgTTRp21-1 through TgTTRp21-5).

Offspring of each founder mouse were generated and examined for transgene expression at the level of RNA, protein, or both (Figs. 1B and 2). The tissue distribution of transgene expression was characteristic of the TTR minigene (Yan et al. 1990). As indicated in Figure 1C, the RNase protection assay detected transgenic, but not endogenous, p21 transcripts as well as endogenous TTR mRNA, providing an internal standard. Primer extension analysis confirmed that the correct transcription start site was used (data not shown). Transgene-specific mRNA was expressed abundantly in the livers of mice from families 1,3 , and 4 and comprised $11.0 \%-79.0 \%$ of the endogenous TTR mRNA (Fig. 1B; Table 1). Family 5, although not examined for mRNA, also expressed the transgene in liver based on protein analysis (see below). Mice of the TgTTRp21-2 family expressed only low levels of transgene mRNA in the liver $\mid<0.1 \%$ of endogenous TTR; Fig. 1B, lane 2). In addition to liver, the TTR minigene vector is expressed in brain choroid plexus epithelium, but only when present in multiple $(6-10)$ copies (Yan et al. 1990). Only one mouse family, TgTTRp214, expressed detectable transgenic transcripts in the brain (Fig. 1B, lane 6), and none of the families expressed detectable p21 protein in this tissue (see below).

Immunoprecipitation followed by Western blotting was used to determine $\mathrm{p} 21$ protein levels in various tissues of transgenic mice relative to normal littermates. A representative experiment is shown in Figure 2A. Our study, as well as other recent reports (Parker et al. 1995; D. Franklin, Y. Li, E. Lee, and Y. Xiong, in prep.), indicates that in normal, fully differentiated tissues, p21 protein levels are very low. Of the nontransgenic tissues we examined, only lung expressed detectable p21 (Fig. 2A, 
TTRp21 transgene

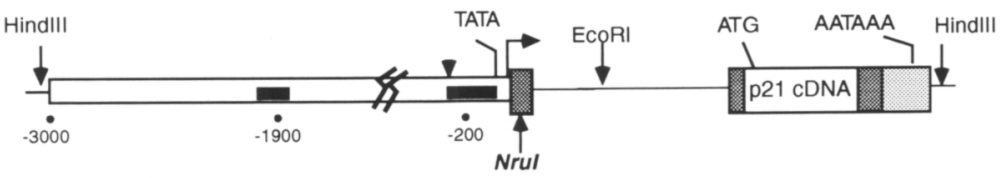

TTR vector and probe

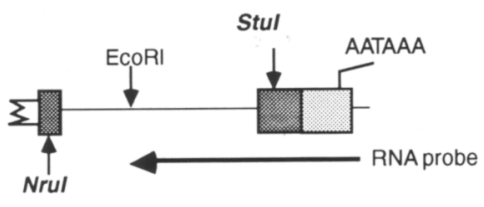

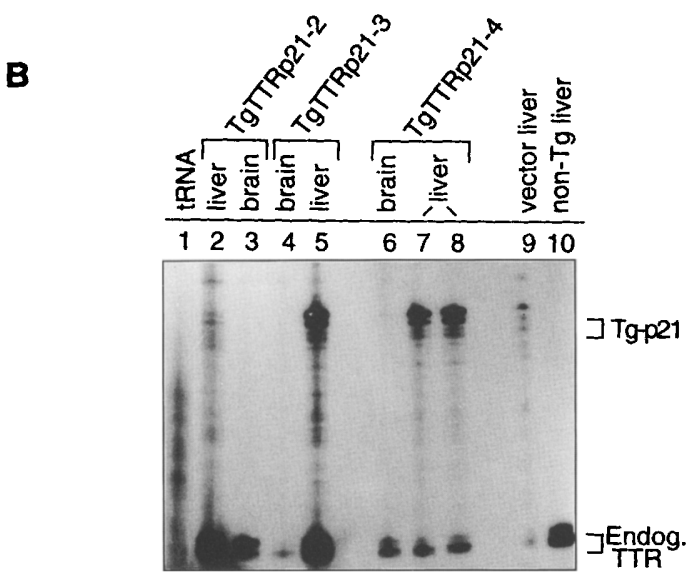

C

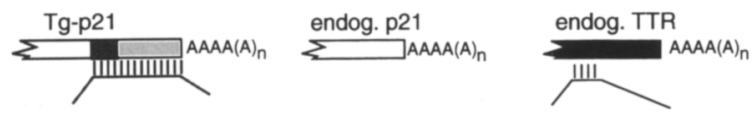

Figure 1. TTR $\mathrm{p} 21$ transgene and RNA Expression. $(A)$ The upstream regulatory region from +1 to $-3 \mathrm{~kb}$ is shown by the small open box. Large boxes denote exons. (Dark stippled box) TTR exonic sequences; (open box) the p 21 cDNA; (light stippled box) a small fragment of the SV40 early region that harbors the polyadenylation sequence. The intron (denoted by a straight line) is the complete TTR first intron. Small solid boxes in the upstream region denote the liver-specific enhancers that direct hepatocyte expression in cell culture (Costa et al. 1986) and in the animal (Yan et al. 1990). The bottom diagram shows the portion of the original pTTR1EXV3 vector from which the RNA probe (horozontal solid arrow) for RNase protection analysis was derived. The mouse p 21 cDNA was inserted into the StuI site of the pTTRExV3 vector. (B) RNase protection analysis of p21 transcripts. Ten micrograms of RNA was subjected to RNase protection analysis as described in $\mathrm{Ma}-$ terials and methods. Protected transgenic p21 fragments migrate as doublet at $\sim 310$ nucleotides, whereas endogenous TTR fragments migrate as a doublet at $\sim 90$ nucleotides. The RNA probe depicted in $A$ hybridizes to the regions of the respective transcripts denoted in $C$. This probe does not hybridize to endogenous p 21 mRNA. tRNA was used as a nonspecific control. Liver RNA from a TgTTR329 transgenic mouse (Yan et al. 1990) that harbors the TTR transgene without the p21 insert was used as a positive control (vector). lane 7). In contrast, the TgTTRp21 transgenic mice consistently expressed abundant $\mathrm{p} 21$ in liver, reflecting the specificity of the TTR regulatory signals, (Fig. 2A, lane 4, and $B$, lanes 2-6). Also characteristic of the TTR minigene (Yan et al. 1990), sporadic p21 expression was observed in the gut of some transgenic mice in one family, TgTTRp21-4 (Fig. 2B, lanes 7-12).

Immunohistochemistry confirmed that p21 was expressed widely in transgenic adult liver hepatocytes (Fig. $3 \mathrm{~A}$, arrows in $\mathrm{B}$ and $\mathrm{D}$ ). Although $\mathrm{p} 21$ was observed in the nucleus of some cells (Fig. 3A, arrows in $\mathrm{B}$ ), it was more commonly localized in the cytoplasm (Fig. 3A, arrows in $\mathrm{D}$ ). The $\mathrm{p} 21$ protein was not detectably expressed in a population of nonhepatocyte cells, which are abundant in transgenic livers (Fig. 3B-D, arrowheads; see below). Endogenous p21 was undetectable in all adult nontransgenic livers examined either by immunoprecipitation-immunoblotting (IP-Western) analysis or by immunohistochemistry (Figs. 2, $\mathrm{A}$ and $\mathrm{B}$, and $3 \mathrm{~A}$, inset).

p21 complexes with cyclin D1/CDK4 in transgenic livers

Current studies suggest that $\mathrm{p} 21$ inhibits progression of the cell cycle by binding cyclin-CDK complexes with sufficient stoichiometry to inactivate the kinase (Harper et al. 1993; Xiong et al. 1993a; Zhang et al. 1994; Harper et al. 1995). In cultured cells, p21 has been observed to complex with all known cyclin-CDK pairs, albeit with different affinities (Zhang et al. 1993, 1994). If p21 functions similarly in vivo, we would expect to find increased association of $\mathrm{p} 21$ with one or more cyclin-CDK pairs in transgenic liver extracts. Analysis of such complexes in mammalian tissues has not been carried out previously because of the limited normal expression of p21.

Using a coupled IP-Western assay, we analyzed the association of $\mathrm{p} 21$ with cyclin and CDK proteins. Total cell lysates were prepared from adult liver and immunoprecipitated with antibodies specific to different cyclins, CDKs, and p21. Immunoprecipitates were resolved by SDS-PAGE and immunoblotted with an antibody specific to p21 (Fig. 4A, and B, bottom) or with a mixture of antibodies to cyclin D1 and CDKs (Fig. 4B, top). The results were the same for all three mouse lines examined (TgTTRp21-3 through TgTTRp21-5) and for multiple mice within each line. A significant level of $\mathrm{p} 21$ protein 
Figure 2. p21 protein expression in transgenic and nontransgenic mouse tissues. Extracts of indicated tissues were generated, and $\mathrm{p} 21$ was immunoprecipitated and detected by Western blotting as described in Materials and methods. Mouse p21 expressed in bacteria served as a marker (B, lane 13). (A) Several tissues from a TgTTRp21-5 mouse. Low levels of p21 were detected in the lung of both the transgenic mouse and its nontransgenic littermate. Abundant p21 was present in the transgenic liver (lane 4) but undetectable in nontransgenic liver $(A$ lane $3 ; B$, lane 1$)$. (B) Liver extracts from several different families of TgTTRp21 mice as well as from several mice within the TgTTRp21-4 lineage as indicated. p21 expression was consistently high in the liver in all transgenic lineages shown. Expression of p21 in transgenic gut of the TgTTRp21-4 lineage is variable from mouse to mouse (lanes 10-12). All signals are representative of several experiments with the exception of the liver sample from TgTTRp21-3 that showed p21 levels comparable to that of TgTTRp21-4 in other experiments.

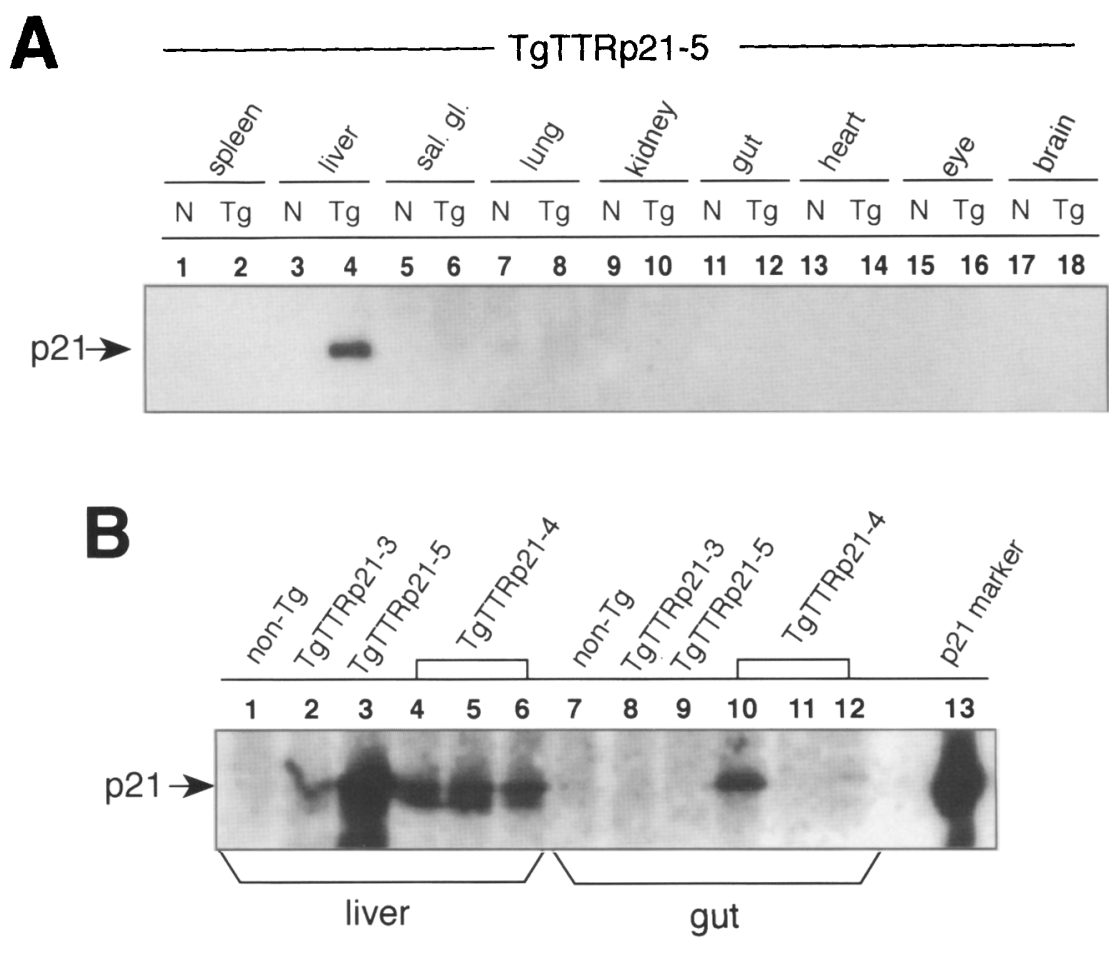

and CDK 4 (Fig. 4, A, lanes 4 and 6, and B, lanes 2,5, and 9). Consistently, no p21 was detected in anti-cyclin D1 or anti-CDK4 immunocomplexes derived from livers of
Figure 3. Relationship of $\mathrm{p} 21$ expression to morphological characteristics of the liver. Immunostaining for p21 expression (red signal) in adult transgenic mouse livers is shown in $A, B, D$, and $F$. In $C$ and $E$, the sections were stained only with hemotoxylin and eosin. $(A, B, D) \mathrm{p} 21$ expression in TgTTRp21 liver is widespread and specific for hepatocytes. (A) Large panel shows TgTTRp21-3 liver; (inset) nontransgenic littermate (magnification, $64 \times$ ). $B$ and $D$ (magnification, $320 \times$ ) show staining is hepatocyte-specific and both cytoplasmic and nuclear. Hepatocytes (arrows) in $B$ show nuclear staining and some cytoplasmic staining. Predominantly cytoplasmic staining, however, is more common $(D)$. (C) Similar section $(320 \times)$ stained with hemotoxylin and eosin shows the presence of abundant nonhepatocyte cells, which do not express p21 ( $B$ and $D$, arrowheads). $E$ and $F$ show, respectively, hemotoxylin and eosin stained and anti-p21-stained sections of a representative regenerative nodule $|n|$ present in some TgTTRp21 transgenic mouse livers. The boundary of the nodule is marked by arrows. Staining for $\mathrm{p} 21$ shows the loss of p21 expression in the nodule and retention of expression outside the nodule.

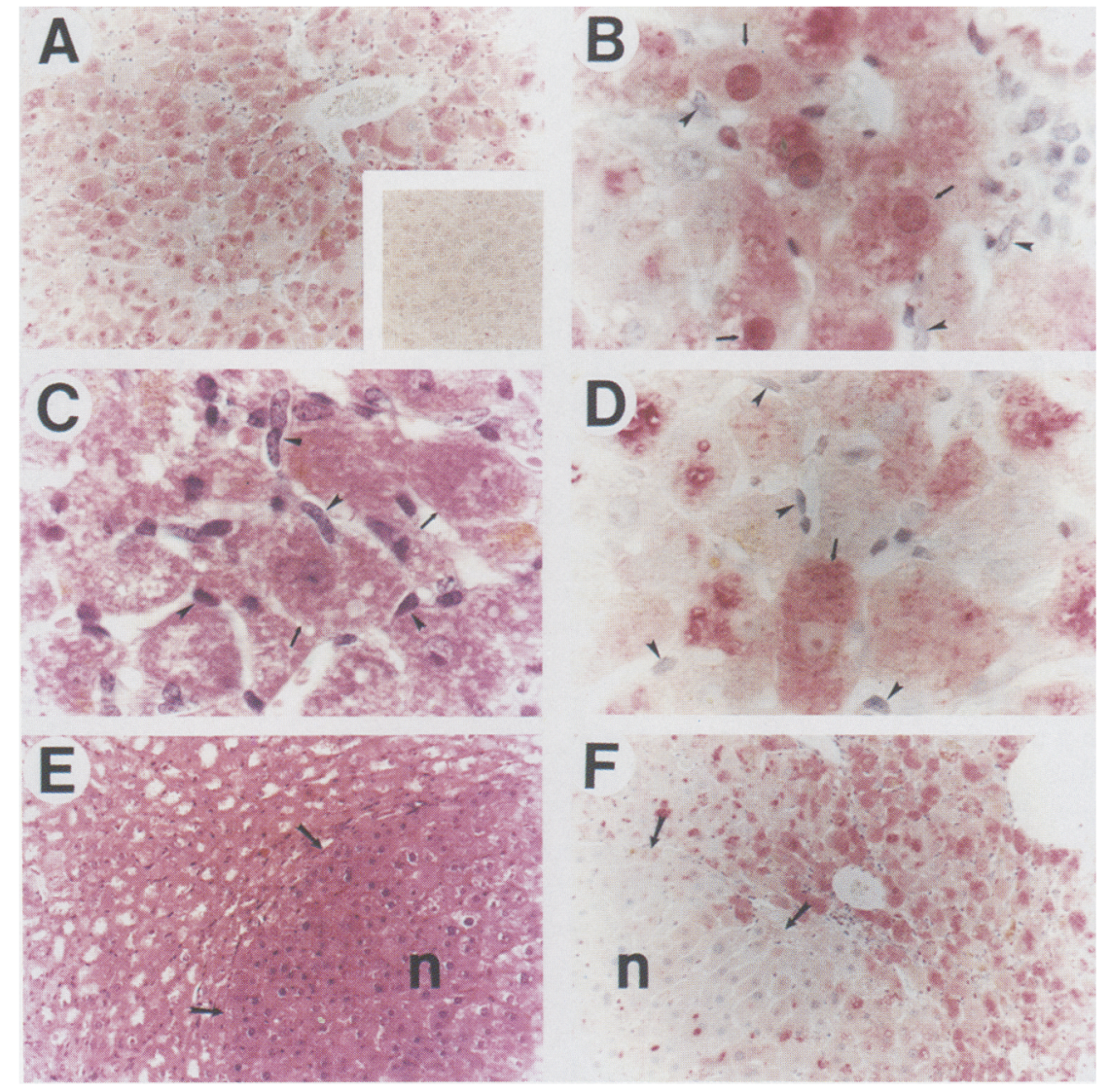


A

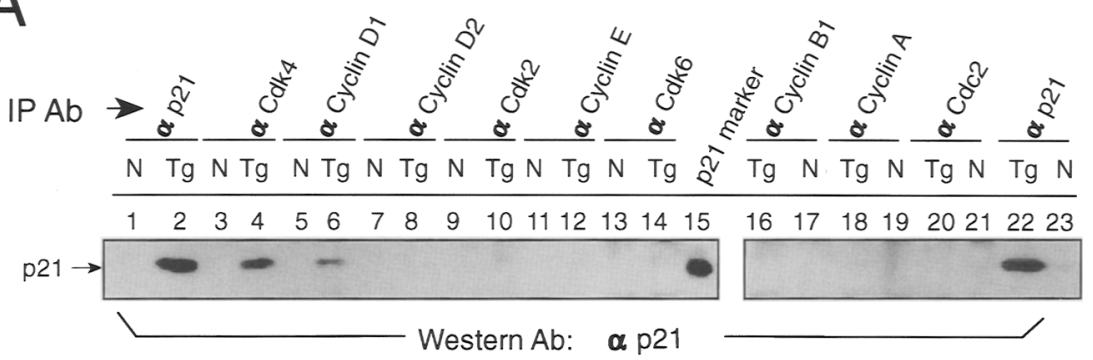

B

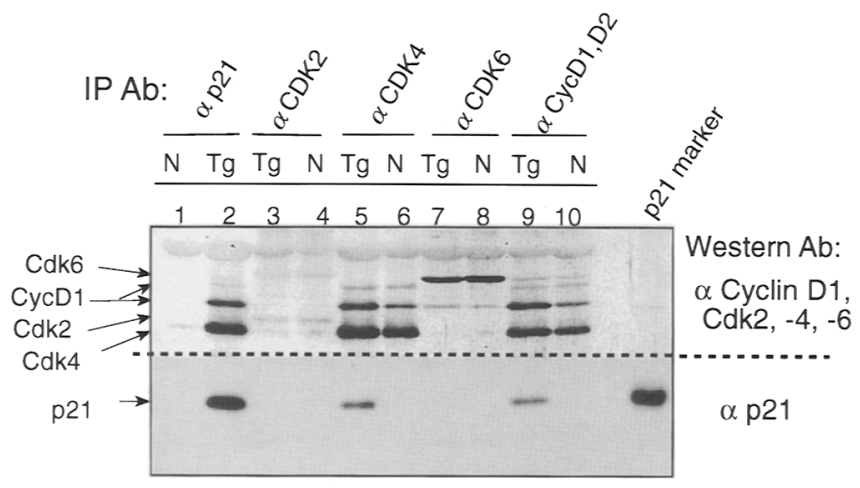

Figure 4. p21 forms a complex with cyclin D1 and CDK4 in transgenic livers. Liver extracts were generated and respective proteins were immunoprecipitated and subjected to Western blotting as described in Materials and methods. (A) The antibody used for Western analysis was specific for p21. (B) The top half of the filter was incubated with antibodies to cyclin D1, CDK2, CDK4, and CDK6, and the bottom half was incubated with the antibody to p21. Extracts were generated from the livers of a transgenic mouse and its nontransgenic littermate. The positions of CDK2, 4, CDK6, cyclin D1, and $\mathrm{p} 21$ are indicated. Mouse p21 produced in bacteria serves as a control. normal animals (Fig. 4A, lanes 3,5). Reciprocally, polypeptides that comigrate with CDK4 and cyclin D1 were detected in anti-p21 immunocomplexes derived from livers of transgenic, but not normal, animals (Fig. 4B, lanes 2 and 1 , respectively). In this and other experiments, we did not detect p21 in anti-cyclins E, A, D2, and $\mathrm{B} 1, \mathrm{CDC} 2, \mathrm{CDK} 2$, and $\mathrm{CDK} 6$ immunocomplexes (Fig. 4A). Preferential association of p21 with CDK4cyclin D1 in liver cells may reflect both expression of higher levels of CDK4-cyclin D1 than other cyclin and CDK proteins in these cells and high affinity of $\mathrm{p} 21$ for CDK4-cyclin D1 complexes.

Both CDK4 and CDK6 were detected readily in transgenic and nontransgenic liver cells, with the level of CDK4 higher than that of CDK6 (Fig. 4B, lanes 5-8). CDK2 was also consistently present, but at a much lower level (Fig. 4B, lanes 3,4). Transgenic expression of p21 did not show any significant effect on the level of any of these CDK proteins. The level of cyclin D1 protein and its association with $\mathrm{CDK} 4$, however, was clearly elevated in liver cells derived from transgenic animals, as determined by both anti-cyclin D1 and antiCDK4 immunoprecipitations (Fig. 4B, lanes 5 and 6, 9 and 10$)$. These observations provide in vivo evidence supporting the notion that $\mathrm{p} 21$ can promote the association of cyclin and CDK subunits (Zhang et al. 1994; Harper et al. 1995).

In transgenic livers, an approximately equal amount of cyclin D1 protein was detected in both anti-p21 and anticyclin D1 immunoprecipitates (Fig. 4B, lanes 2,9). Similarly, the same amount of CDK4 protein was also detected in both anti-p21 and anti-CDK4 immunocomplexes (Fig. 4B, lanes 2,5). These results indicate that most, if not all, of the cyclin D1 and CDK4 proteins were complexed with $\mathrm{p} 21$. This represents a significant departure from normal liver, in which neither p21 nor its association with cyclin D1-CDK4 was detected, raising the possibility that the function of cyclin D-CDK4 enzyme is likely impaired in the livers of transgenic mice.

\section{p21 expression interferes with postnatal liver development}

Expression of p21 in the livers of transgenic mice was clearly detrimental to their postnatal development. A summary of the phenotypic abnormalities present in these mice is presented in Tables 1 and 2 . In each of the families highly expressing the p21 transgene (TgTTRp21-1, TgTTRp21-3-TgTTRp21-5), liver mass was low $149 \%-62 \%$ the mass of normal littermate livers; Table 2). The affected mice also demonstrated stunted growth in comparison to their normal littermates (Fig. $5 A, B)$, possibly related to the failure of liver growth. The body weight of affected mice compared with normal littermates ranged from $50 \%$ to $90 \%$. Moreover, mice in each of the affected families had a shortened life span, generally dying by 2-3 months of age (Fig. $5 \mathrm{C}$ ). None of these effects were observed in control mice expressing the TTR vector alone (Yan et al. 1990) nor in mice that abundantly expressed a transgenic protein of similar size (p53DD) from the same vector (Table 1; T. Bowman, $H$. Symonds, L. Gu, M. Oren, and T. Van Dyke, in prep.). Therefore, the liver abnormalities were attributable specifically to the effects of $\mathrm{p} 21$ and were not the result of nonspecific toxicity.

Histological examination of p21-expressing livers re- 
Table 1. Summary of TgTTRp21 transgenic mice

\begin{tabular}{|c|c|c|c|c|c|}
\hline \multirow[b]{2}{*}{$\begin{array}{l}\text { Transgenic } \\
\text { line }\end{array}$} & \multicolumn{3}{|c|}{ Expression } & \multirow[b]{2}{*}{ Phenotype } & \multirow[b]{2}{*}{$\begin{array}{l}\text { Cyclin/Cdk } \\
\text { complex }\end{array}$} \\
\hline & cell/tissue $^{\mathrm{a}}$ & $\begin{array}{c}\text { mRNA } \\
(\% \text { endogenous })^{\mathrm{b}}\end{array}$ & protein $^{\mathrm{b}}$ & & \\
\hline $\begin{array}{l}\text { TgTTR329 } \\
\text { (vector) }\end{array}$ & $\begin{array}{l}\text { hepatocyte } \\
\text { (brain, eye) } \\
\text { (gut) }\end{array}$ & $\begin{array}{c}150 \\
\text { variable }\end{array}$ & N.D. & normal & \\
\hline TgTTRp21-1 & hepatocyte ${ }^{c}$ & 18.0 & N.D. & $\begin{array}{l}\text { runted }(\mathrm{R}) \\
\text { lower liver weight }(\mathrm{LW}) \\
\text { hepatocyte deficit }(\mathrm{HD})^{\mathrm{C}} \\
\text { premature death }(\mathrm{PD})\end{array}$ & N.D. \\
\hline TgTTRp21-2 & hepatocyte & 0.1 & N.D. & normal & N.D. \\
\hline TgTTRp21-3 & hepatocyte & 11.0 & ++ & R, LW, HD, PD & cyclin D1/Cdk4 \\
\hline TgTTRp21-4 & $\begin{array}{l}\text { hepatocyte } \\
\text { (gut) } \\
\text { (brain) }\end{array}$ & 79.0 & ++ & $\mathrm{R}, \mathrm{LW}, \mathrm{HD}, \mathrm{PD}$ & cyclin D1/Cdk4 \\
\hline $\begin{array}{l}\text { TgTTRp21-5 } \\
\text { TgTTRDD-1 } 13^{\mathrm{d}} \\
\text { (control) }\end{array}$ & $\begin{array}{l}\text { hepatocyte } \\
\text { hepatocyte } \\
\text { (brain) }\end{array}$ & $\begin{array}{l}\text { N.D. } \\
<10.0\end{array}$ & $\begin{array}{c}+++ \\
++++\end{array}$ & $\begin{array}{l}\mathrm{R}, \mathrm{LW}, \mathrm{ND}, \mathrm{PD} \\
\text { normal }\end{array}$ & cyclin D1/Cdk4 \\
\hline
\end{tabular}

(N.D.) not determined; (R) runted; (LW) lower liver weight; (HD) hepatocyte deficit; (PD) premature death.

${ }^{a}$ Expression from the TTR regulatory region is consistently high in liver hepatocytes of most transgenic families and does not depend on transgene copy numbers. Expression in brain and eye depends on the presence of multiple copies. Expression in gut occurs only within some families and not in all mice within the family (Yan et al. 1990).

bmRNA and protein levels given only for liver tissues. mRNA levels are relative to endogenous TTR mRNA level.

${ }^{\mathrm{c}}$ Mice of the TgTTR p21-1 family have not been examined by in situ methods, hepatocyte expression is inferred based on expression in liver, and a hepatocyte deficit is inferred from low liver weight as occurs in the other families.

${ }^{\mathrm{d}}$ Truncated form of 553 protein expressed under TTR promoter control (T. Bowman, H. Symonds, L. Gu, M. Oren, and T. Van Dyke, in prep.).

vealed a cellular disturbance that resulted in decreased liver mass. In normal livers $>25$ hepatocytes comprise the length of hepatic plates between each adjacent portal triad and central vein (Fig. 6A,B). In the p2l transgenic mice, however, as few as six hepatocytes were contained in hepatic plates (Fig. 6C). Although the precise number of hepatocytes in each hepatic plate varied, it was consistently fewer than normal. Consequently, the hepatocyte number in all transgenic mice was diminished greatly and average distances separating portal and central hepatic veins were small (Table 2 ; Fig. $6 \mathrm{C}$ ).

In addition to a reduction in the number of hepatocytes, transgenic livers also contained an abundance of cells histologically identifiable as oval cells (Fig. 3A; Table 2). Oval cells are not identifiable in normal livers; however, these cells proliferate under conditions in which hepatocytes are destroyed or are prevented from proliferating in response to liver damage (Fausto 1990). Under experimental conditions, oval cells can serve as a precursor to both hepatocytes and bile duct epithelial cells (Evarts et al. 1987, 1989). However, it is not known whether they normally constitute a stem cell compartment. The abundance of these cells in p21-expressing transgenic livers suggests that the normal response to insufficient hepatocyte numbers, that is, hepatocyte proliferation, is impaired.

Table 2. TgTTRp21 liver characteristics

\begin{tabular}{|c|c|c|c|c|c|}
\hline \multirow{2}{*}{$\begin{array}{l}\text { Transgenic } \\
\text { line }\end{array}$} & \multirow{2}{*}{$\begin{array}{l}\text { Liver mass }^{\mathrm{a}} \\
(\% \text { controls })\end{array}$} & \multirow{2}{*}{$\begin{array}{l}\text { Portal to central length of } \\
\text { hepatic plates } \\
\text { (\% controls) }\end{array}$} & \multirow{2}{*}{$\begin{array}{l}\text { Mega-nuclei }{ }^{c} \\
(\%)\end{array}$} & \multicolumn{2}{|c|}{ Composition $^{\mathrm{d}}(\%)$} \\
\hline & & & & hepatocyte & nonhepatocyte \\
\hline non- $\mathrm{Tg}$ & 100.0 & $100.0 \pm 16.4\langle n=2|$ & $0.1(n=7)$ & 61.9 & $38.1(n=7)$ \\
\hline TgTTRp21-3 & $61.6(n=2)$ & $60.0 \pm 13.4(n=2)$ & N.D. & N.D. & N.D. \\
\hline TgTTRp21-4 & $53.9(n=11)$ & $94.5 \pm 28.0(n=4)$ & $2.0(n=7)$ & 43.5 & $56.5(n=7)$ \\
\hline TgTTRp21-5 & $48.5(n=1)$ & $73.1 \pm 6.8 \quad(n=1)$ & N.D. & N.D. & N.D. \\
\hline
\end{tabular}

${ }^{a}$ Liver mass was compared to that of normal littermates, where $n$ (number of mice examined) is $>1$ an average is presented.

bortal to central lengths of hepatic plates were measured with the aid of microscopy. The average of five to eight separate measurements per liver is presented, where $n$ (the number of animals) is $>1$ the average values are presented.

${ }^{c}$ The number of hepatocyte nuclei of normal size and those larger than $20 \mu \mathrm{m}$ in diameter were counted in 10 fields, at $50 \times$ magnification. Values were expressed as a percent and averaged for seven mice.

${ }^{\mathrm{d}}$ Hepatocytes and nonparenchymal cells were counted as in $\mathrm{c}$ and expressed as percent of the sum of the two. Values presented represent an average of seven individual mice. 

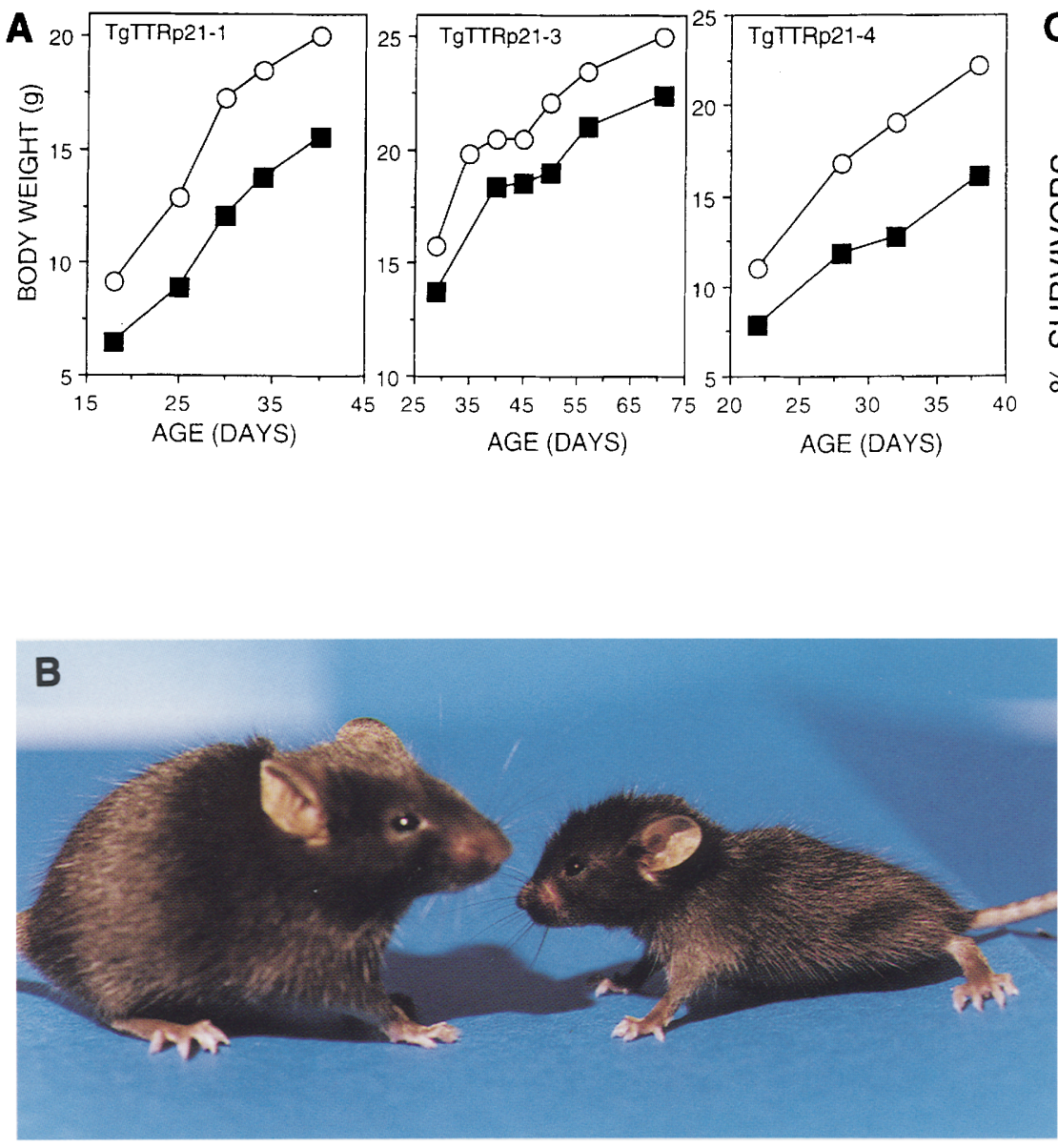

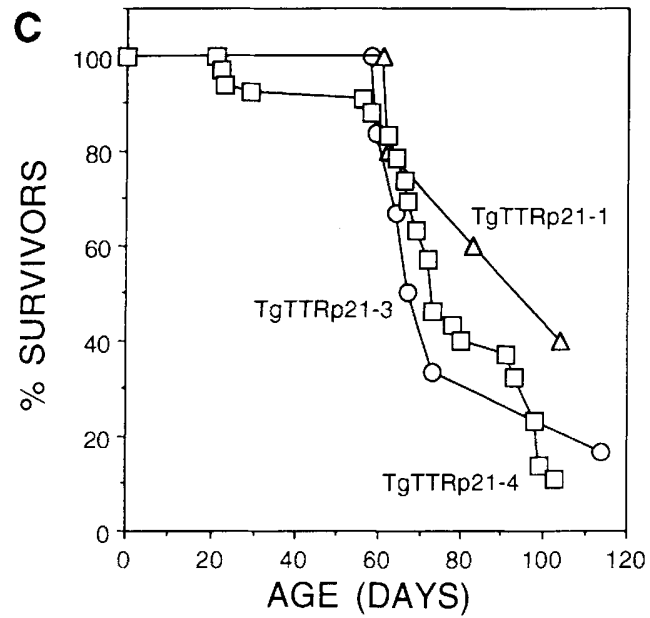

Figure 5. Phenotype of TgTTR p 21 transgenic mice. $(A)$ Representative growth curves of transgenic mice and their normal littermates for three separate litters from three families of mice. Total body weight was determined at indicated ages. $(B)$ A representative photograph of one such pair of mice at 42 days of age. The mouse on the left is the nontransgenic littermate of the transgenic mouse on the right. Survival times are indicated for three TgTTRp21 families in $C$. The percent of surviving mice is plotted as a function of time. Survival time was measured at the time when mice were dying and were sacrificed.
Interestingly, three of eight TgTTRp21 livers examined from three distinct families contained nodular foci of hepatocytes. Because liver has the capacity to regenerate, these nodules could have resulted from a signal to overcome the deficit of hepatocytes. BrdU incorporation analysis confirmed that cells within the nodules were proliferating (data not shown). However, p21 in sufficient levels is thought to inhibit the cell cycle /Sherr and Roberts 1995). Thus, we determined whether $\mathrm{p} 21$ expression was sustained in the nodules. Immunohistochemi$\mathrm{cal}$ staining indicated that $\mathrm{p} 21$ protein was not expressed in most cells of the nodular foci (Fig. 3F). A dramatic boundary was found between arrested hepatocytes that expressed $\mathrm{p} 21$ and proliferating cells in the nodules that did not express detectable p21 (Fig. 3E,F). This observation indicates that high levels of $\mathrm{p} 21$ are incompatible with hepatocyte proliferation. Furthermore, because p21-expressing cells did not inhibit the proliferation of adjacent nonexpressing cells, the effect of $\mathrm{p} 21$ is cell autonomous. The hepatocytes in nodules that did not express p21 may have resulted from the deletion or inactivation of the transgene in precursor cells (Sandgren et al. 1991).

Finally, an interesting aberration that consistently appeared in transgenic livers was the presence of hepatocytes with nuclei two to four times the diameter of the largest normal nuclei in nontransgenic livers. Moreover, hepatocytes with these giant, highly polyploid nuclei comprised up to $2 \%$ of the hepatocytes in adult transgenic livers (Table 2). The abundant presence of these cells could indicate blockage of some cells in $G_{2}$ or the accumulation of senescent cells (see Discussion).

\section{p21 inhibits proliferation of postnatal hepatocytes}

In cultured cells, high levels of $\mathrm{p} 21$ have correlated with cell-cycle arrest and, in some cases, apoptosis (El-Deiry et al. 1994). Furthermore, p53 (an established transcriptional regulator of $\mathrm{p} 21$ ) is known to induce apoptosis in some types of cells (Yonish-Rouach et al. 1991; Shaw et al. 1992). Theoretically, either activity could have caused the observed reduction in mature hepatocyte numbers observed in TgTTRp21 mice. To determine the impact of p21 expression on hepatocytes during development, we analyzed liver samples by in situ detection of p21 expression, DNA synthesis, and apoptosis during fetal and postnatal development.

Immunohistochemical detection of $\mathrm{p} 21$ showed only weak signals of similar magnitude in both TgTTRp21 transgenic and nontransgenic littermate livers from embryonic day 13 (E13) of fetal development to birth (data not shown). In nontransgenic littermates, the p21 pro- 

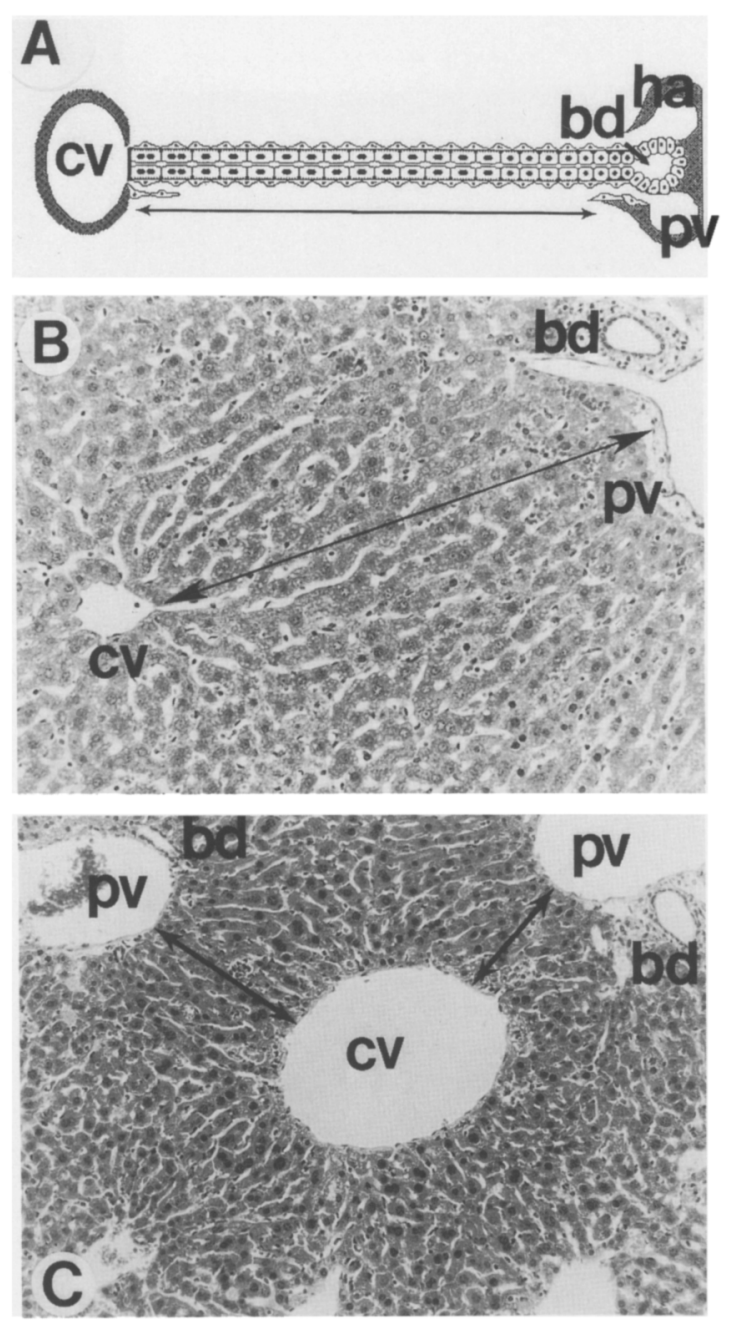

Figure 6. Liver organization is disrupted in transgenic mice. Hepatocyte organization in normal liver is depicted in $A$ and is shown for a nontransgenic littermate in $B$. Transgenic (TgTTRp21-3) liver is shown in $C$. Arrows on diagram $(A)$ and photomicrographs (hemotoxylin and eosin-stained sections) show distances in the hepatic plate between the central vein (cv) and the portal triad, including hepatic artery (ha), bile duct (bd), and portal vein $(\mathrm{pv})$. Magnification $(50 \times)$ is the same in $B$ and $C$. [ $A$ is modified from Segal et al. (1992).]

tein was undetectable in postnatal liver from birth to adulthood. In contrast, significant levels of p21 appeared in the postnatal liver of transgenic animals $\sim 15-20$ days of age and thereafter remained consistently high (data not shown). This onset of expression coincided with the time at which a discrepancy between transgenic and nontransgenic liver mass became evident ( $2-3$ weeks of age).

In correlation with increased $\mathrm{p} 21$ expression, histological evidence of liver abnormalities also appeared in transgenic animals during postnatal days 15-20. During this time, the population of nonhepatocyte cells increased and the hepatocyte number decreased compared to that of normal littermates (Fig. 7A). The decrease in hepatocyte number during this postnatal period appeared to result from a p21-induced cell-cycle block as evidenced from a dramatic reduction in cells undergoing DNA synthesis (Figs. 7B, and 8, A and B). In the normal postnatal liver, a significant number of hepatocytes proliferate, contributing to the overall growth in the liver during this stage of development (Figs. 7B and 8A) (Vassy and Kraemer 1993). In contrast, the TgTTRp21 transgenic mice showed a marked reduction in the percentage of S-phase hepatocytes beginning around postnatal day 7 and persisting into the postweaning period (Fig. 7B). Furthermore, the abnormally abundant oval-like cells, which do not express p21 (Fig. 3B,D), proliferated at a high rate as indicated by high levels of BrdU incorporation into nuclei (Fig. 8B).

The in situ TUNEL assay for apopotic cells /see Materials and methods) was used to determine whether an increase in apoptotic death by $\mathrm{p} 21$ may also contribute to an adult hepatocyte deficit. Hepatocyte apoptosis was minimal in both normal and TgTTRp21 mice (data not shown), indicating that cell death was not significantly induced by $\mathrm{p} 21$ expression. Thus, the reduction in hepatocyte number and resulting pathological aberrations observed in TgTTRp21 adult livers can be accounted for by a p21-induced inhibition of postnatal hepatocyte proliferation.

\section{p21 halts cell-cycle progression in regenerating liver}

To determine the impact of $\mathrm{p} 21$ on cell-cycle progression more directly, we experimentally manipulated the hepatocyte cell cycle by performing partial hepatectomies (PHs) on TgTTRp21 transgenic and normal littermate mice. Normal adult hepatocytes are quiescent but can be induced to proliferate through one to three rounds of cell division by partial resection of the liver (Higgins and Anderson 1931; Grisham 1962; Bucher 1963). Because induction of this cell-cycle activity is parasynchronous, hepatocytes can be systematically followed through cellcycle phases. Sham operations and one of three or two of three PHs were performed on several transgenic and nontransgenic mice of the TgTTRp21-4 lineage. Mice were injected with BrdU, and livers were analyzed histologically for hepatocyte morphology, DNA synthesis, and the presence of mitotic figures at various times postsurgery (Figs. 9 and 10).

Expression of p21 in transgenic hepatocytes clearly led to a block of the cell cycle, whereas hepatocytes of normal littermates progressed normally through the first mitotic division. As expected, both transgenic and nontransgenic hepatocytes were quiescent prior to $\mathrm{PH}$ (Fig. 9A, pairs 3 and 5, before PH). Normal hepatocytes reached a peak of DNA synthesis at $36 \mathrm{hr}$ post-PH, whereas hepatocyte DNA synthesis was reduced dramatically $(0.5 \%-14.5 \%$ of normal) in livers of four of five transgenic mice examined between 24 and $60 \mathrm{hr}$ post- $\mathrm{PH}$ (Figs. 8, C and D, and 9A). In all animals, BrdU incorporation into gut epithelial cells was normal (data not shown|, providing a control for BrdU injection and uptake. Furthermore, because the data in Figure 9A have 
Figure 7. Postnatal liver development is disrupted in transgenic mice. $(A)$ The abundance of hepatocytes and small nonhepatocyte cells in normal and transgenic litters. Both hepatocytes and nonhepatocyte cells were counted via microscopy. An average of counts from 10 fields at $50 \times$ magnification was taken and values are presented as a percent of the sum of the two numbers. In normal livers thatched bars), during postnatal liver development, hepatocytes are the most abundant population of cells as shown on the left, whereas nonhepatocyte cells are less abundant as shown on the right. However, in transgenic p21 expressing livers /stippled bars), hepatocytes constitute a minor cell population (left), whereas nonhepatocyte cells are abundant (right). The increase in this population can be accounted for by the appearance of cells with oval cell morphology. This situation persists throughout postnatal development when p21 expression is detected above normal levels (see text). (B) BrdU incorporation into hepatocytes was measured on various days of postnatal development as described in $\mathrm{Ma}$ terials and methods. Hepatocytes of nontransgenic littermates (hatched bars) continue to proliferate during this time, while the labeling index of hepatocytes is reduced in transgenic littermates (stippled bars). The light stippled bars denote the percentage of hepatocytes incorporating BrdU compared with the total number of hepatocytes within the same liver. The dark stippled bars have been corrected for the low number of hepatocytes present in transgenic livers and represent the percentage of BrdU incorporating hepatocytes compared to the number of hepatocytes in the normal littermate of the same age.

not been corrected for the reduction of overall hepatocyte numbers in $\mathrm{p} 21$-expressing livers, these percentages underestimate the level of S-phase inhibition. Although transgenic animal 5 (48 hr post- $\mathrm{PH}$ ) showed weaker reduction in S-phase activity (66\% of normal), this did not reflect a lag in the peak of DNA synthesis as evidenced from the low percentage of S-phase cells $\mid<2.8 \%$ of normal) at the transgenic 60 -hr time point (Fig. 9A). As in post-natal livers of young TgTTRp21 mice, most of the $\mathrm{BrdU}$ incorporation in livers of post- $\mathrm{PH}$ transgenic mice occurred in the abundant population of oval-like cells (Figs. 8D and 10, D and F). Of interest, several "giant" highly polyploid hepatocyte nuclei in TgTTRp21 mice incorporated $\mathrm{BrdU}$, indicating that these cells might have escaped an S-phase block and were arrested in $G_{2}$ phase.

Analysis of mitotic indexes showed that hepatocytes in normal mice reached a peak of $M$-phase activity by 48 hr after PH (Figs. 9B and 10, A,C, and E). However, the TgTTRp21 hepatocytes were not observed to enter $M$ phase, even in cases where S-phase activity was substantial (Fig. 9, mouse 5 and Fig. 10, B,D, and F). These data also suggest the possibility that $\mathrm{p} 21$-expressing cells may be blocked in $G_{2}$ as well as in $G_{1}$. Further systematic analysis of hepatocyte subpopulations for DNA content and cyclin-CDK expression after $\mathrm{PH}$ will be required to determine whether $G_{2}$ arrest occurs in a subset of hepatocytes. The analysis presented here, however, confirms that p21 expression impedes cell proliferation and further demonstrates that this effect is dominant even in the presence of a powerful mitotic signal.

\section{Discussion}

This report describes the first in vivo functional analysis of a CDK inhibitor by targeted expression. In this study we directed expression of $\mathrm{p} 21$ specifically to hepatocytes. Our results indicate that appropriate levels of p21 are critical for normal liver development and demonstrate that inappropriate expression leads to severe abnormalities that can be explained by interference with proper control of the hepatocyte cell cycle. In multiple examples in this study, expression of the $p 21$ transgene appears to severely impair cell proliferation. During the postnatal period in transgenic mice, inhibition of hepatocyte proliferation correlates with the increase of $\mathrm{p} 21$ 
Figure 8. DNA synthesis in the livers of weanling $(A, B)$ and hepatectomized adult $(C, D)$ mice. Dark nuclear staining shows the presence of BrdU in newly synthesized

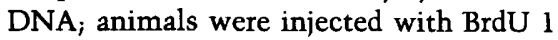
hr before sacrifice. Arrows show examples of DNA synthesis in hepatocyte nuclei; arrowheads $(B$ and $D)$ show DNA synthesis in small nonhepatocyte cells. Sections from normal weanling mice $(A)$, and from adult mice assayed $36 \mathrm{hr}$ after two-thirds PH $(C)$, showed much higher levels of DNA synthesis in hepatocyte nuclei than did transgenic littermates shown in $B$ and $D$, respectively. Livers from transgenic animals overexpressing p21 contained few hepatocyte nuclei in which DNA was being synthesized, but many more small nonhepatocyte cells that stained positively for DNA synthesis $(B, D)$. Magnification in all panels, $50 \times$. Quantitation of DNA synthesis in developing animals and in adult hepatectomized animals is shown in Figs. 7 and 9 , respectively.
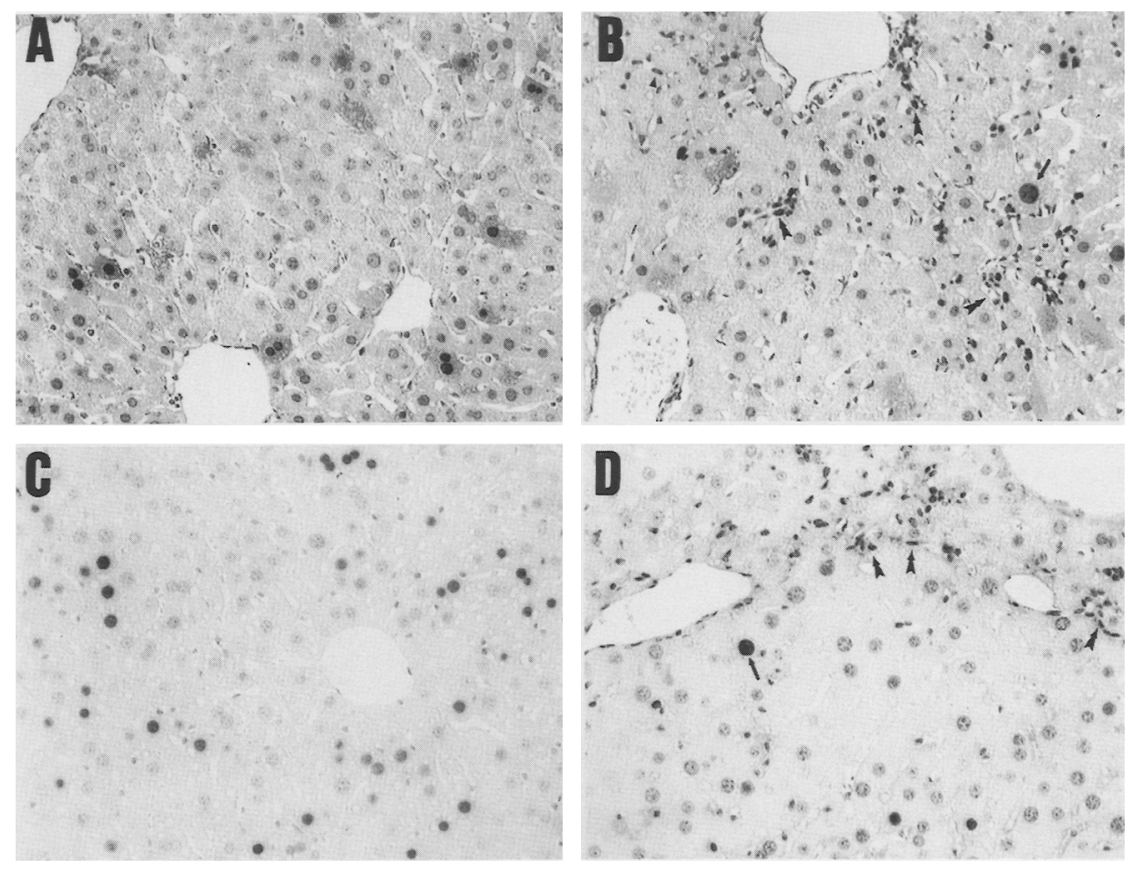

expression above normal levels. Such inhibition of cell division at this stage can fully account for the deficit of hepatocytes observed in adult liver. The impact of $\mathrm{p} 21$ on the cell cycle is even more pronounced in adult animals subjected to partial hepatectomy. Hepatocytes from hepatectomized transgenic mice display almost complete inhibition of induced cell division. Transgenic livers also contain increased numbers of proliferating oval-like cells, which do not express $\mathrm{p} 21$, and occasional focal growths of hepatocytes, which have lost expression of the $p 21$ transgene.

\section{Biological function of $p 21$}

We have shown here that enforced $\mathrm{p} 21$ expression arrests the hepatocyte cell cycle in an otherwise genetically and physiologically normal environment. Moreover, this function overrides even the powerful mitogenic signals that stimulate liver regeneration. p21 was first observed to inhibit cell proliferation in cultured cells (El-Deiry et al. 1993; Harper et al. 1993; Xiong et al. 1993a). However, its regulation by the tumor suppressor $\mathrm{p} 53$ led to the speculation that $\mathrm{p} 21$ may be the downstream effector not only of p53-induced growth arrest but also of p53dependent apoptosis. Consistent with this possibility, some studies have correlated increased levels of p21 with apoptosis (El-Deiry et al. 1994). Our studies in liver provide evidence that $\mathrm{p} 21$ can block the hepatocyte cell cycle in $G_{1}$ and possibly also in $G_{2}$ but show no indication that $\mathrm{p} 21$ triggers apoptosis. Recently, mice homozygous for a null mutation in the $p 21$ gene were used to examine the known p53-dependent biological activities. Primary fibroblasts derived from these mice were partially defective in DNA damage-induced $G_{1}$ arrest, but thymocytes

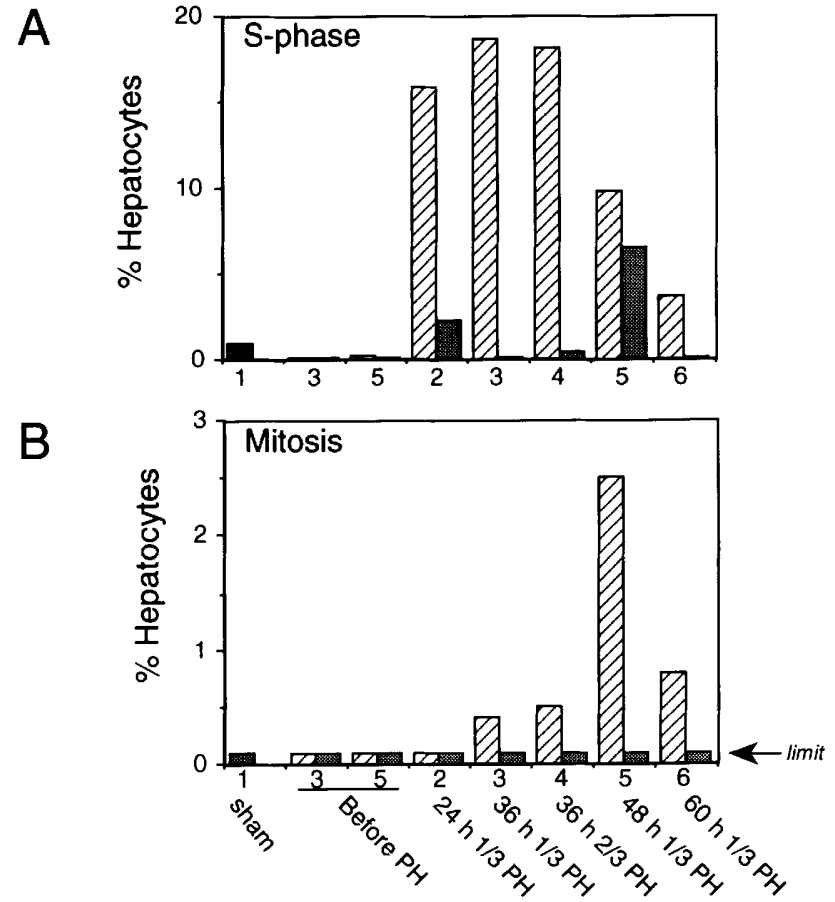

Figure 9. Cell cycle analysis of p21 expressing livers subsequent $\mathrm{PH}$. PHs were performed as described in Materials and methods on TgTTRp21-4 transgenic mice (stippled bars) and normal littermates (hatched bars). The percentage of hepatocytes incorporating BrdU were quantified to determine S-phase cells in $A$. Mitotic figures were assessed morphologically (Fig. $10)$ for values in $B$. Dramatic inhibition of $S$ phase occurs in most transgenic mice post- $\mathrm{PH}$ and inhibition of entry into $M$ phase is indicated for all transgenic mice. One-third of the liver was removed for all $\mathrm{PHs}$, with the exception of mouse pair 4, in which two-thirds of the liver was removed. 
Figure 10. Inhibition of cell division by p21 expression. Normal littermate $\{A, C, E)$ and transgenic mouse $(B, D, F)$ livers $48 \mathrm{hr}$ post-PH (mouse pair 5, Fig. 9B) were analyzed for mitotic figures (by hemotoxylin and eosin staining; $A, B)$ and DNA synthesis (by BrdU staining; $C, D, E, F\}$. Mitotic figures are abundant in the normal nontransgenic mouse $1 \mathrm{~m}$, in $A, C, E)$. These mitotic figures have incorporated $\operatorname{BrdU}\{C, E)$, and a number of $\mathrm{S}$-phase cells are also present $(\mathrm{s}$, in $C, E)$. In the transgenic mice, however, mitotic figures are not present. Several aberrantly large nuclei are present $\{p$ for polyploidy, in $B, D, F \mid$ and some of these nuclei have incorporated low levels of $\operatorname{BrdU}(D)$. BrdU has readily incorporated into the nonhepatocyte cells (arrowheads, $D, F$.). Original magnification is $64 \times$ in $A, B, C, D ; 320 \times$ in $E, F$.

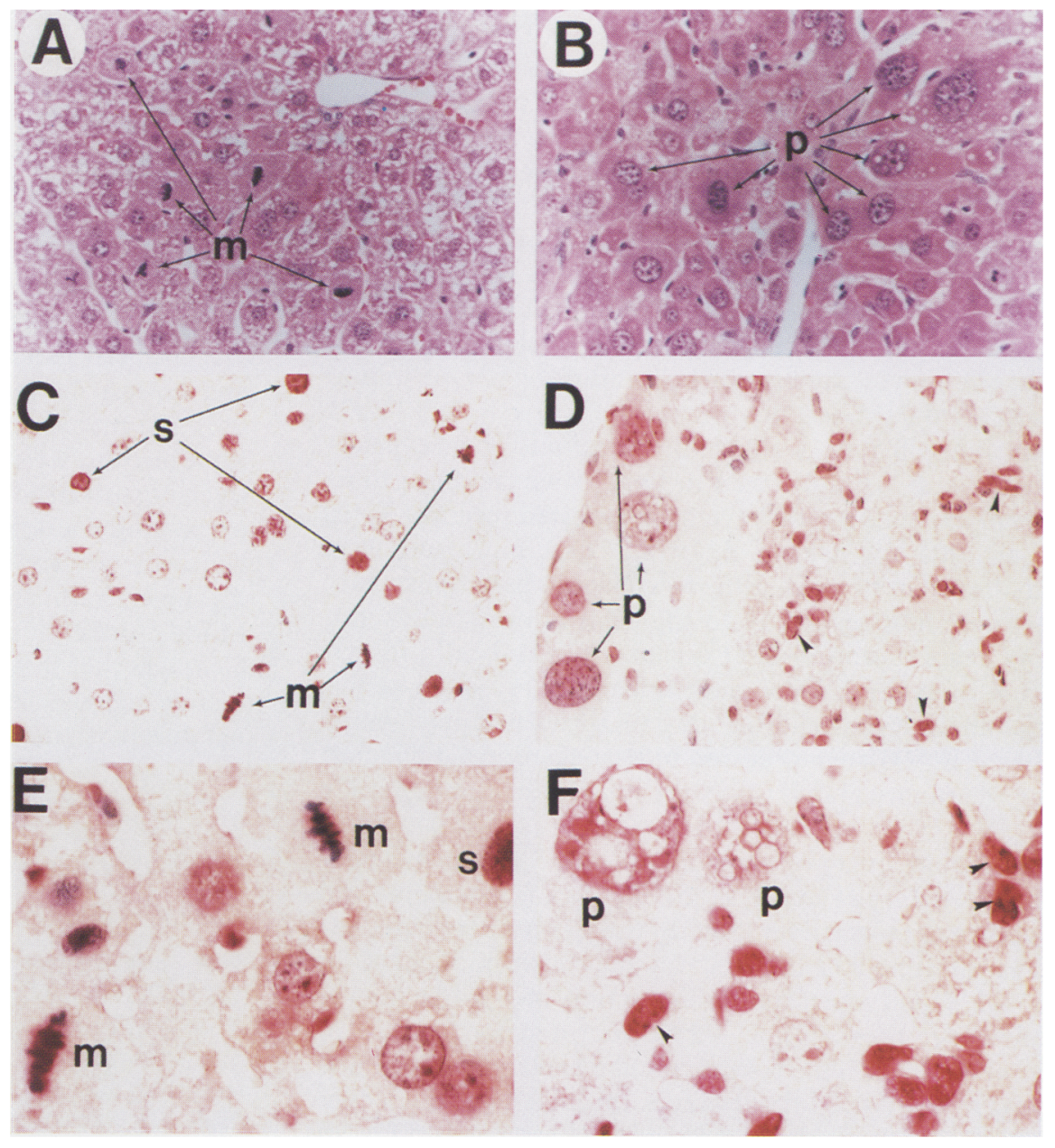

and intestinal cells were fully competent to undergo DNA damage-induced apoptosis, responses that are defective in p53-null animals (Brugarolas et al. 1995; Deng et al. 1995). As with our in vivo results, this study indicates that $\mathrm{p} 21$ functions in p53-dependent cell-cycle arrest but not in cell death, ruling out the simple notion that damaged cells first arrest by a p53-dependent mechanism, and subsequently undergo apoptosis. Downstream of $\mathrm{p} 53$, these events appear to involve distinct effectors.

Fibroblasts derived from the p21-null mice are only partially defective in $G_{1}$ arrest compared to p53-null fibroblasts, indicating that $\mathrm{p} 21$ is not the only $\mathrm{p} 53$-regulated component of this response (Deng et al. 1995). In our studies, however, p21 expression appeared sufficient to induce cell-cycle arrest in the absence of p53 regulation. Such a result indicates that redundancy or compensation by other factors may occur in $p 21$-null fibroblasts; alternatively, cell-type specificity may affect the mechanism of cell-cycle arrest. The possibility for compensation underscores the importance of using both dominant gain-of-function analysis (as in the current studies) with loss-of-function studies (as with null mice) to fully understand gene function. Although mice lacking an intact p21 gene appear normal (Brugarolas et al. 1995; Deng et al. 1995), inappropriate expression of p21 is not well tolerated. The fact that $\mathrm{p} 21$ appears to have a role in $\mathrm{p} 53$ mediated $G_{1}$ arrest, together with the observation that p53, but not p21 (Shiohara et al. 1994), is frequently mutated in human cancers, may also be an indication that there is redundancy in functions downstream of p53. Alternatively, apoptosis rather than $G_{1}$ arrest is the critical p53 biological activity with an impact on tumorigenesis. Further experimentation examining p53-dependent tumor models in p21-null mice and in mice inappropriately expressing p21, as described here, will be required to directly test these possibilities.

In cultured cells and in cell-free systems, $\mathrm{p} 21$ can complex with a variety of cyclin-CDK pairs (Xiong et al. 1993b; Zhang et al. 1993). On the basis of immunochemical data from this study, p21 was observed predominantly in complex with cyclin D1-CDK4 in transgenic adult liver. Previous studies also showed cyclin D1 to be present in resting liver and throughout the cell cycle in regenerating liver (Lu et al. 1992; Albrecht et al. 1993; Koch et al. 1994; Loyer et al. 1994). Thus, the apparent specificity of $\mathrm{p} 21$ for cyclin D1-CDK4 in this tissue could reflect the prevalence of this pair in hepatocytes. 
Whether differential affinities or specificities also contribute to the observed selectiveness will require further studies using isolated $\mathrm{p} 21$-expressing hepatocytes. Nonetheless, the predominant association of $\mathrm{p} 21$ with a majority of the liver cyclin D1-CDK4 in these mice implicates cyclin D1-CDK4 as a key regulator of liver growth control. The importance of cyclin D1 in liver growth control is underscored by studies implicating amplification and overexpression of the cyclin Dl gene in aggressive human hepatocellular carcinoma (Nishida et al. 1994). On the basis of the cell-cycle block observed here and the previously established ability of p21 to inhibit associated CDK activity, the effect elicited in TgTTRp21 mice should reflect a specific knockout phenotype for both cyclin D1 and CDK4 in liver. Mice lacking a functional cyclin D1 gene have been reported recently /Fantl et al. 1995; Sicinski et al. 1995). These mice, too, were smaller than normal, although specific liver abnormalities were not reported. On the basis of our studies, further examination of liver organization and cell proliferation in cyclin D1-deficient mice may reveal an abnormal phenotype. Reported abnormalities in mice lacking the cyclin Dl gene occurred in tissues /retina and lactating mammary gland) that were not targeted in our study of $\mathrm{p} 21$.

Although entry of hepatocytes into S phase is clearly inhibited in p21-expressing cells during postnatal and posthepatectomy liver growth, there is indirect evidence that a fraction of hepatocytes may also be blocked in $\mathrm{G}_{2} / \mathrm{M}$. Upon synchronous induction of the hepatocyte cell cycle after $\mathrm{PH}, \mathrm{p} 21$-expressing hepatocytes fail to enter $M$ phase. This result could be explained by the low percentage of cells that make it through $\mathrm{S}$ phase, in conjunction with the short time of $M$ phase resulting in an undetectably low percentage of M-phase cells. However, this explanation does not account for the appearance of abnormally enlarged nuclei that comprise up to $2 \%$ of the hepatocytes in transgenic livers /this compares to $<0.1 \%$ in normal livers). In normal livers of young mice, hepatocyte ploidy can range from $2 \mathrm{~N}$ to $8 \mathrm{~N}$, with the polyploid cells being both bi- and mononuclear. In our studies, however, transgenic nuclei were often significantly larger (two to four times the diameter of the largest normal nuclei) and were shown to synthesize DNA.

Significantly, in normal rodent and human livers, the percentage of polyploid nuclei, as well as the overall ploidy, increase with aging (Kudryavtsev et al. 1993). Because $\mathrm{p} 21$ has been implicated in cellular senescence and was originally identified as a senescence factor (Noda et al. 1994), it will be of major interest to determine whether inappropriately high levels of p 21 drive hepatocytes into senescence. Whether the appearance of this phenotype results from the ability of p21 to induce a $G_{2}$ block, to drive senescence, or both, will require more detailed studies on isolated postnatal hepatocytes. Further studies using the mice described here and similar mice with an inducible transgene should help define the role of p21 in senescence and determine the extent to which the observed phenotypes may also reflect a role for $\mathrm{p} 21$ in the differentiation process.
Hepatocyte differentiation, liver development, and regeneration

The TgTTRp21 mice may provide an important model for the study of liver growth and development. Normally, during the postnatal period, hepatocytes continue to proliferate and undergo functional and structural changes leading to their terminally differentiated adult configuration. The hepatocytes become functionally heterogeneous, with distinguishable zones occurring along the tract from portal to central veins. These hepatocytes display both ultrastructural and metabolic differences, and express distinct subsets of liver-specific gene products (Gumucio 1989; Jungermann 1995). The period from birth to weaning is critical in the establishment of liver organization and hepatocellular function. In p21expressing livers, premature cessation of the hepatocyte cell cycle clearly results in aberrant liver organization. As shown in this report, the major effect is the reduction in the number of mature hepatocytes. However, it is not clear whether this signal, which overrides normal proliferative signals, also aberrantly contributes to the terminal differentiation of hepatocytes.

\section{Materials and methods}

Cloning of murine p21 cDNA and construction of transgene

PCR primers were designed /sequences 5'-ACCATGGCCAATCCTGGTGATGTCCG- ${ }^{\prime}$ ' and $5^{\prime}$-AGGATCCAAGCTTCAGGGTTTTCTCTTGCAG-3') to clone the coding sequence of the $\mathrm{p} 21 \mathrm{cDNA}$ from a murine fibroblast cDNA library in $\lambda$ gt 10 (gift of K. Suzuki, University of North Carolina, Chapel Hill). The $5^{\prime}$ primer used in the amplification contained a single-base-pair mutation (underlined) changing nucleotide 4 from $\mathrm{T}$ to $\mathrm{G}$ to introduce a Ncol site at the $5^{\prime}$ end of the cDNA. This mutation changed serine 2 to alanine. This mutation does not affect the in vitro or in vivo activity of $\mathrm{p} 21$ (this study; Xiong et al. 1993a; data not shown).

The p21 PCR product was digested with HindIII, blunt-ended with Klenow polymerase, and cloned into the unique StuI site of the pTTR1ExV3 vector (Fig. 1A; see below). The resulting clone, pTTREXV3-mp21, was sequenced at the University of North Carolina Automated DNA Sequencing Facility on a model 373A DNA Sequencer (Applied Biosystems) using the Taq DyeDeoxy Terminator Cycle Sequencing Kit (Applied Biosystems). The coding sequence is identical to a murine p21 clone identified by Huppi et al. (1994) in a comparative sequence analysis of murine p21 cDNAs.

The pTTR1ExV3 expression vector contains transcriptional regulatory sequences from the murine TTR gene consisting of 3 $\mathrm{kb}$ of upstream sequence, the first exon and intron, and much of the second exon. pTTR1ExV3 was derived from pTTR1 (Costa et al. 1986, 1988) using site-directed mutagenesis to remove two ATG start codons (one in each exon) and to introduce cloning sites. Briefly, pTTR1ExV3 was constructed by cloning the SacIHindII fragment of PTTR1 into the PTZ18U phagemid vector, followed by removal of the BamHI site of the PTTR 1 polylinker by SmaI-Sall digestion, Klenow blunting of the Sall site, religation, and site-directed mutagenesis of the resulting subclone to mutate the ATG in the first exon creating a unique NruI site and to introduce a StuI site in place of the ATG 12 bases into the second exon. The pTTRl transgene is expressed consistently in 
liver hepatocytes as well as in the brain choroid plexus epithelium when present in many copies (Yan et al. 1990).

For $\mathrm{p} 21$ expression in bacteria, pBluescript $\mathrm{KS}(+1-\mathrm{mp} 21$ (containing the p21 cDNA PCR product described above) was digested with $\mathrm{NcoI}$ and $\mathrm{BamHI}$ and the resulting p21-encoding fragment was cloned into the bacterial expression vector $\mathrm{pET} 21 \mathrm{~d}(+)$ (Novagen). The control $\mathrm{p} 21$ protein was prepared by induction of pET21d-mp21 expression in bacteria with $0.2 \mathrm{mM}$ IPTG followed by harvest of the cells 3-5 hr later, sonication in lysis buffer, and clarification by centrifugation.

\section{Production and screening of transgenic mice}

Plasmid pTTR-mp21 was digested with HindIII to generate a 4.9-kb transgene fragment (Fig. 1A), which was isolated by gel electrophoresis, purified, and injected into (B6D2F1XB6D2F1) fertilized eggs as described previously (Yan et al. 1990). Founder mice and their offspring were screened using a PCR assay specific for the transgene; the $5^{\prime}$ primer $\left(5^{\prime}\right.$-AAAGTCCTGGATGCTGTCCGAG- $\left.3^{\prime}\right)$ hybridizes to the second TTR exon, and the $3^{\prime}$ primer (5'-CAGACATGATAAGATACATTGATG-3') hybridizes to the SV40 3' tag. DNA was isolated from tail or toe samples as described previously (Yan et al. 1990).

\section{RNA isolation and analysis}

Total cellular RNA was isolated from tissues using the RNAzol method as suggested by the manufacturer (Cinna/Biotecx, Friendswood, TX). Nuclease protection analysis of transgenic transcripts was carried out as described previously (Yan et al. 1990) except that the incubation temperature was increased from $32^{\circ} \mathrm{C}$ to $37^{\circ} \mathrm{C}$ and the digests were electrophoresed in a $6 \%$ polyacrylamide gel. The gels were dried and exposed to Kodak XAR-5 film (1-7 days) with an intensifying screen. Quantitation of expression levels was determined utilizing a Phosphorimager (Molecular Dynamics) and calculating the transgenic transcript signal compared to that from endogenous TTR transcripts in the same lane as described previously (Yan et al. 1990). Levels given in Table 1 are the average of values obtained in two to four assays for a single mouse of each lineage.

Primer extension analysis to determine the 5 ' start site of the transgenic RNA was performed by the addition of $10 \mu \mathrm{g}$ of liver RNA to a reaction mixture containing $5 \mathrm{mM} \mathrm{MgCl}_{2}, 1 \mathrm{~mm}$ dATP, $1 \mathrm{~mm}$ dGTP, $1 \mathrm{~mm}$ dTTP, $1 \times$ PCR buffer II, 1 unit of RNase inhibitor, 2.5 units of murine leukemia virus (MuLV) reverse transcriptase (Perkin Elmer), $100 \mathrm{ng}$ of a mouse p21specific primer (5'-CGGAACAGGTCGGACATCACC-3'), and $10 \mu \mathrm{Ci}$ of ${ }^{32} \mathrm{P}$-labeled dCTP (NEN-Dupont) in $20 \mu \mathrm{l}$ total volume. The reaction was incubated at $42^{\circ} \mathrm{C}$ for $15 \mathrm{~min}, 99^{\circ} \mathrm{C}$ for 5 $\mathrm{min}$, and $5^{\circ} \mathrm{C}$ for $5 \mathrm{~min}$, in a Perkin Elmer 9600 thermocycler. After incubation, the reactions were extracted once with phenol/chloroform and precipitated with 0.1 volume of $3 \mathrm{M} \mathrm{NaOAc}$ and two volumes of $100 \%$ ethanol. The pellet was then resuspended in $5 \mu \mathrm{l}$ of formamide loading buffer $198 \%$ formamide, $1 \%$ bromophenol blue, $1 \%$ xylene cyanol) and electrophoresed in a $6 \%$ polyacrylamide gel.

\section{IP-Western analysis}

IP-Western analysis was performed as described previously (Symonds et al. 1993; Jenkins and Xiong 1995). Briefly, tissue lysates were prepared by homogenization of tissues (fresh or frozen at $\left.-80^{\circ} \mathrm{C}\right)$ in lysis buffer $[50 \mathrm{~mm}$ Tris- $\mathrm{Cl}(\mathrm{pH} 7.5), 1 \mathrm{~mm}$ $\mathrm{Na}_{3} \mathrm{VO}_{4}, 150 \mathrm{mM} \mathrm{NaCl}, 50 \mathrm{~mm} \mathrm{NaF}, 1 \mathrm{~mm}$ DTT, $\left.0.5 \% \mathrm{NP}-40\right]$ with protease inhibitors (Jenkins and Xiong 1995) at $4^{\circ} \mathrm{C}$, followed by sonication. Lysates were cleared and IP-Western anal- ysis carried out as described (Jenkins and Xiong 1995). Lysate containing $5 \mathrm{mg}$ of protein was used for each assay. Antibody amounts were $0.5 \mu \mathrm{g}$ (Santa Cruz Biotechnology antibodies), $1 \mu 1$ of affinity-purified antibody or 1-2 $\mu$ l of crude rabbit serum (see below). Proteins were resolved in SDS-polyacrylamide gels (15\% acrylamide) and transferred to Hybond-ECL nitrocellulose membranes (Amersham) in a Bio-Rad semidry electroblotting apparatus. Blots were blocked in blocking buffer [5\% nonfat dry milk in PBST (PBS at PH 7.4, 0.1\% Tween 20)] for $1 \mathrm{hr}$, incubated $2 \mathrm{hr}$ to overnight at $25^{\circ} \mathrm{C}$ in primary antibody, diluted 1:5000 in blocking buffer, and then $1 \mathrm{hr}$ with horseradish peroxidase (HRP)-conjugated goat anti-rabbit secondary antibody (ZYMED), diluted 1:5000 in blocking buffer. Proteins were detected with ECL detection reagents (Amersham).

\section{Antibodies}

Antibodies specific for p21 (C-19, SC-397), CDK4 (C-22, SC260), CDK6 (C-21, SC-177), cyclin D2 (C17, SC-181), and cyclin E (M-20, SC-481) were from Santa Cruz Biotechnology, Inc. Rabbit sera raised against human CDK2, cyclin A, and cyclin B1 have been described previously (Xiong et al. 1993a). Rabbit sera specific for mouse cyclin D1, cyclin D2, or cyclin D3 were the generous gifts of C. Sherr (St. Jude's Children's Hospital, Memphis, TN).

\section{Histology and Immunohistochemistry}

Tissues were routinely fixed in $10 \%$ buffered formalin (Sigma) and embedded in paraffin. For histology, sections $(3-8 \mu \mathrm{m})$ were stained with hemotoxylin and eosin. For immunohistochemistry, sections were deparaffinzied by two 5 -min incubations in Hemo-De (Fisher), followed by several changes of ethanol $(100 \%, 95 \%, 70 \%$, and $35 \%)$ and rehydration in PBS. For p21 immunostaining, sections were blocked in $5 \%$ normal goat serum (NGS) in PBS for $30 \mathrm{~min}$ and then incubated at $4^{\circ} \mathrm{C}$ overnight with anti-p21 antibody (1:50 in PBS containing 5\% NGS; Santa Cruz Biotechnology, Inc.). For BrdU assays, sections were incubated in $2 \mathrm{~N} \mathrm{HCl}$ for $30 \mathrm{~min}$ at $25^{\circ} \mathrm{C}$ and washed several times with PBS. After blocking in 5\% horse serum, sections were incubated with anti-BrdU antibody (Amersham Cell Proliferation Kit) for $1-2 \mathrm{hr}$ at $25^{\circ} \mathrm{C}$. After three washes in PBS, sections were incubated in biotin-conjugated secondary antibody (1:350 in PBS, 2\% NGS, Vector Laboratories) for $30 \mathrm{~min}$ at $25^{\circ} \mathrm{C}$. Sections were then washed twice with TS buffer $[50 \mathrm{mM}$ Tris- $\mathrm{HCl}$ ( $\mathrm{pH} 7.6$ ), $150 \mathrm{~mm} \mathrm{NaCl}, 0.1 \%$ Tween 20], incubated for 30 min in the $\mathrm{ABC}-\mathrm{AP}$ detection reagent (Vector Laboratories), washed twice in TS buffer, incubated for $30 \mathrm{~min}$ in alkaline phosphate substrate (Vector Laboratories), and washed several times with $\mathrm{dH}_{2} \mathrm{O}$ before counterstaining with hematoxylin, dehydrating by graded ethanol washes, and two changes in HemoDe and mounting.

\section{BrdU labeling and partial hepatectomy}

For routine BrdU labeling, animals were injected intraperitoneally with labeling reagent containing 5-bromo-2'-deoxyurdine (BrdU, Amersham Life Science; $0.03 \mathrm{mg} / \mathrm{gram}$ body weight) and were sacrificed by $\mathrm{CO}_{2}$ asphyxiation 1 or $2 \mathrm{hr}$ later. $\mathrm{PH}$ was performed according to the method of Noguchi et al. (1991). Surgery was performed under avertin anesthesia. The abdominal cavity was entered through a transverse skin incision that was placed bilaterally just below and parallel to the rib section. The large left lateral lobe $(1 / 3)$ or additionally the right lateral lobe $(2 / 3)$ were ligated and removed. After $23,35,47$, or $59 \mathrm{hr}$, animals were injected with BrdU and sacrificed $1 \mathrm{hr}$ later 
as described above. Control animals (before $\mathrm{PH}$ ) were injected with BrdU intraperitoneally $1 \mathrm{hr}$ before surgery.

\section{In situ detection of apoptosis}

Formalin fixed paraffin-embedded liver sections $(7 \mu \mathrm{m})$ were deparaffinized in xylene and rehydrated through graded ethanols. The TUNEL assay (Gavrieli et al. 1992) was performed as described previously (Symonds et al. 1994) using the Apoptag in situ apoptosis kit (Oncor). DNA ends were tagged in situ with digoxygenin-dNTP using terminal deoxytransferase. Apoptotic cells (which had undergone extensive DNA fragmentation) were then detected with anti-digoxigenin HRP (Oncor) for 30 $\mathrm{min}$ at $25^{\circ} \mathrm{C}$. Slides were washed with PBS $(4 \times 5 \mathrm{~min})$ and incubated with $0.05 \% \mathrm{DAB}$ (Sigma) for $2.5 \mathrm{~min}$ at $25^{\circ} \mathrm{C}$.

\section{Acknowledgments}

We thank Drs. David Brenner and Piet DeGroen for advice on this project and on the manuscript and Drs. Robert Costa and Michael Rosenberg for critical comments; Lin Zhou for excellent technical assistance; Ken McGaffin for construction of pTTRExV3; Dr. Claus Hellerbrand for instruction on partial hepatectomy; and Kim Berns and Tracey Bartolotta of the University of North Carolina Pulmonary histology core facility for excellent histological sample preparation. We thank John Kim, Stacey Bridge, and Lisa Moore for assistance in manuscript preparation and the other members of the Van Dyke and Xiong laboratories for many useful suggestions. This work was supported by grants from the National Institutes of Health /CA46283 and DK42910 to T.V.D. and CA65572 to Y.X.). T.V.D. is the recipient of a research career development award from the National Cancer Institute. Y.X. is a recipient of an American Cancer Society Junior Faculty Award and a Pew Scholar in Biomedical Science.

The publication costs of this article were defrayed in part by payment of page charges. This article must therefore be hereby marked "advertisement" in accordance with 18 USC section 1734 solely to indicate this fact.

\section{Note added in proof}

de Nooij and Hariharan (Science 270: 983-985) recently expressed human p21 in the developing eye of Drosophila melanogaster with results similar to those described here. Expression of p21 inhibited proliferation (but not differentiation) and resulted in fewer cells than normal.

\section{References}

Albrecht, J.H., J.S. Hoffman, B.T. Kren, and C.J. Sherr.1993. Cyclin and cyclin-dependent kinase 1 mRNA expression in models of regenerating liver and human liver diseases. Am. I. Physiol. 265: G857-G864.

Aprelikova, O., Y. Xiong, and E.T. Liu. 1995. Both p16 and p21 families of CDK inhibitors block CDK phosphorylation by the CDK activating kinase (CAK). I. Biol. Chem. 270(31): 18195-18197.

Brugarolas, J., C. Chandrasekaran, J.I. Gordon, D. Beach, T. Jacks, and G.J. Hannon. 1995. Radiation-induced cell cycle arrest compromised by p21-deficiency. Nature 377:552557.

Bucher, N.L.R. 1963. Regeneration of mammalian liver. Int. Rev. Cytol. 15: 245-300.

Chen, J., P.K. Jackson, M.W. Kirschner, and A. Dutta. 1995. Separate domains of $\mathrm{p} 21$ involved in the inhibition of cdk kinase and PCNA. Nature 374: 386-388.

Costa, R.H., E. Lai, and J.E. Darnell. 1986. Transcriptional control of the mouse prealbumin (transthyretin) gene: Both promoter sequences and a distinct enhancer are cell specific. Mol. Cell. Biol. 6: 4697-4708.

Costa, R.H., D.R. Grayson, K.G. Xanthopoulos, and J.E. Darnell. 1988. A liver-specific DNA-binding protein recognizes multiple nucleotide sites in regulatory regions of transthyretin, alpha 1- antitrypsin, albumin, and simian virus 40 genes. Proc. Natl. Acad. Sci. 85: 3840-3844.

Datto, M.B., Y. Li, J.F. Panus, D.J. Howe, Y. Xiong, and X.-F. Wang. 1995. Transforming growth factor $\beta$ induces the cyclin-dependent kinase inhibitor p21 through a p53-independent mechanism. Proc. Natl. Acad. Sci. 92: 5545-5549.

Deng, C., P. Zhang, J.W. Harper, S.J. Elledge, and P. Leder. 1995. Mice lacking $\mathrm{p} 211^{\mathrm{CIP} / \mathrm{WAFl}}$ undergo normal development, but are defective in Gl checkpoint control. Cell 82: 675-684.

Dulic, V., W. Kaufman, S. Wilson, T. Tlsty, E. Lees, J. Harper, S. Elledge, and S. Reed. 1994. p53-dependent inhibition of cyclin-dependent kinase activities in human fibroblasts during radiation-induced G1 arrest. Cell 76: 1013-1023.

Elbendary, A., A. Berchuck, P. Davis, L. Havrilesky, R.C. Bast, J.D. Inglehart, and J.R. Marks. 1994. Transforming growth factor beta 1 can induce CIP /WAF1 expression independent of the p53 pathway in ovarian cancer cells. Cell Growth Differ. 5(12): 1301-1307.

El-Deiry, W.S., T. Tokino, V.E. Velculescu, D.B. Levy, R. Parsons, J.M. Trent, D. Lin, W.E. Mercer, K.W. Kinzler, and B. Vogelstein. 1993. WAF1, a potential mediator of $\mathrm{p} 53$ tumor suppression. Cell 75: 817-825.

El-Deiry, W.S., J.W. Harper, P.M. O'Connor, V.E. Velculescu, C.E. Canman, J. Jackman, and J.A. Pietenpol. 1994. WAF1/ CIP1 is induced in p53-mediated Gl arrest and apoptosis. Cancer Res. 54: 1169-1174.

Evarts, R.P, P. Nagy, E. Marsden, and S.S. Thorgeirsson. 1987. A precursor relationship exists between oval cells and hepatocytes in rat liver. Carcinogenesis 8: 1737-1740.

Evarts, R.P., P. Nagy, H. Nakatsukasa, E.R. Marsden, and S.S. Thorgeirsson. 1989. In vivo differentiation of rat liver oval cells into hepatocytes. Cancer Res. 49: 1541-1547.

Fantl, V., G. Stamp, A. Andrews, I. Rosewell, and C. Dickson. 1995. Mice lacking cyclin Dl are small and show defects in eye and mammary gland development. Genes \& Dev. 9: 2364-2372.

Fausto, N. 1990. Hepatocyte differentiation and liver progenitor cells. Curr. Opin. Cell. Biol. 2: 1036-1042.

Flores-Rozas, H., Z. Kelman, F. Dean, Z. Pan, J. Harper, S. Elledge, M. O'Donnell, and J. Hurwitz. 1994. Cdk-interacting protein 1 directly binds with proliferating cell nuclear antigen and inhibits DNA replication catalyzed by the DNA polymerase delta holoenzyme. Proc. Natl. Acad. Sci. 91: 8655-8659.

Gavrieli, Y., Y. Sherman, and S.A. Ben-Sasson. 1992. Identification of programmed cell death in situ via specific labeling of nuclear fragmentation. J. Cell Biol. 119: 493-501.

Grisham, J.W. 1962. A morphologic study of deoxyribonucleic acid synthesis and cell proliferation in regenerating rat liver; autoradiography with thymidine-H3. Cancer Res. 22: 842849.

Guan, K-L., C.W. Jenkins, Y. Li, M.A. Nichols, X. Wu, C.L. O'Keefe, A.G. Matera, and Y. Xiong. 1994. Growth suppression by p18, a p16 $6^{I N K 4 / M T S 1}$ - and $14^{\text {INK4B/MTS2 }}$-related CDK6 inhibitor, correlates with wild-type $\mathrm{pRb}$ function. Genes \& Dev. 8: 2939-2952.

Guan, K.-L., C.W. Jenkins, Y. Li, C.L. O’Keefe, S. Noh, X. Wu, M. Zariwala, A.G. Matera, and Y. Xiong. 1996. Isolation of 
p19INK4d, a p16-related Inhibitor specific to CDK6 and CDK4. Mol. Biol. Cell (in press).

Gumucio, J.J. 1989. Hepatocyte heterogeneity and liver function. Cell. Biol. Rev. 19: 1-161.

Guo, K., J. Wang, V. Andres, R.C. Smith, and K. Walsh. 1995. MyoD-induced expression of p21 inhibits cyclin-dependent kinase activity upon myocyte terminal differentiation. Mol. Cell. Biol. 15(7): 3823-3829.

Halevy, O., B.G. Novitch, D.B. Spicer, S.X. Skapek, J. Rhee, G.J. Hannon, D. Beach, and A.B. Lassar. 1995. Terminal cell cycle arrest of skeletal muscle correlates with induction of $\mathrm{p} 21$ by MyoD. Science 267: 1018-1021.

Hannon, G. and D. Beach. 1994. p15INK4B is a potential effector of TGF-beta-induced cell cycle arrest. Nature 371: 257261.

Harper, J.W., G.R. Adami, N. Wei, K. Keyomars, and S.J. Elledge. 1993. The 21 Cdk-interacting protein Cipl is a potent inhibitor of G1 cyclin-dependent kinases. Cell 75: 805-816.

Harper, J.W., S.J. Elledge, K. Keyomarsi, B. Dynlacht, L.H. Tsai, P. Zhang, S. Dobrowolski, C. Bai, L. Connell-Crowley, E. Swindell, M.P. Fox, and N. Wei. 1995. Inhibition of cyclindependent kinases by p21. Mol. Biol. Cell 6: 387-400.

Higgins, G.M and R.M. Anderson. 1931. Experimental pathology of the liver. Arch. Pathol. 12: 186-202.

Hirai, H., M.F. Roussel, J. Kato, R.A. Ashmun, and C.J. Sherr. 1995. Novel INK4 proteins, p19 and p18, are specific inhibitors of the cyclin D-dependent kinases CDK4 and CDK6. Mol. Cell. Biol. 15: 2672-2681.

Hunter, T. and J. Pines. 1994. Cyclins and cancer II: Cyclin D and $\mathrm{CDK}$ inhibitors come of age. Cell 79: 573-582.

Huppi, K., D. Siwarski, J. Dosik, P. Michieli, M. Chedid, S. Reed, B. Mock, D. Givol, and J. Mushinski. 1994. Molecular Cloning, sequencing, chromosomal localization and expression of mouse p21 (Waf1). Oncogene 9: 3017-3020.

Jenkins, C.W. and Y. Xiong. 1995. Immunoprecipitation and immunoblotting in cell cycle studies. In Cell cycle: Materials and methods (ed. M. Paganol, pp. 250-263. Springer-Verlag, New York, NY.

Jiang, H., Z.-Z. Su, F. Collart, E. Huberman, and P. Fisher. 1994. Induction of differentiation in human promyelocytic HL-60 leukemia cells activates 21, WAF1/CIP1, expression in the absence of p53. Oncogene 9: 3397-3406.

Jungermann, K. 1995. Zonation of metabolism and gene expression in liver. Histochemistry 103: 81-91.

Kamb, A., N.A. Gruis, J. Weaver-Feldhaus, Q. Liu, K. Harshman, S.V. Tavtigan, E. Stockert, R.S. Day, B.E. Johnson, and M.H. Skolnick. 1994. A cell cycle regulator potentially involved in genesis of many tumor types. Science 264: 436-440.

Kato, J., M. Matsuoka, K. Polyak, J. Massague, and C.J. Sherr. 1994. Cyclic AMP-induced G1 phase arrest mediated by an inhibitor ( $\mathrm{p} 27^{\mathrm{Kip} 1}$ ) of cyclin-dependent kinase 4 activation. Cell 79: 487-496.

Koch, K.S., X.P. Lu, and H.L. Leffert. 1994. Primary rat hepatocytes express cyclin D1 messenger RNA during their growth cycle and during mitogenic transitions induced by transforming growth factor-alpha. Biochem. Biophys. Res. Commun. 204(1): 91-97.

Kudryavtsev, B.N., M.V. Kudryavtsev, G.A. Sakuta, and G.I. Stein. 1993. Human hepatocyte polyploidization kinetics in the course of life cycle. Virchows Arch. B Cell Pathol. Incl. Mol. Pathol. 64(6): 387-393.

Lee, M-H., I. Reynisdottir, and J. Massague. 1995. Cloning of p5 $7^{K I P 2}$, a cyclin-dependent kinase inhibitor with unique domain structure and tissue distribution. Genes \& Dev. 9: 639-649.

Li, C.Y., L. Suardet, and J.B. Little. 1995. Potential role of Waf1/
Cip $1 / \mathrm{p} 21$ as a mediator of TGF- $\beta$ cytoinhibitory effect. $J$. Biol. Chem. 270(10): 4971-4974.

Li, R., S. Waga, G. Hannon, D. Beach, and B. Stillman. 1994. Differential effects by the $\mathrm{p} 21$ inhibitor on PCNA-dependent DNA replication and repair. Nature 371: 534-537.

Loyer, P., D. Glaise, S. Cariou, G. Baffet, L. Meijers, and C. Guguen-Guillouzo. 1994. Expression and activation of cdks ( 1 and 2) and cyclins in the cell cycle progression during liver regeneration. J. Biol. Chem. 269(4): 2491-2500.

Lu, X.P., K.S. Koch, D.J. Lew, V. Dulic, J. Pines, S.I. Reed, T. Hunter, and H.L. Leffert. 1992. Induction of cyclin mRNA and cyclin-associated histone $\mathrm{H} 1$ kinase during liver regeneration. J. Biol. Chem. 267(5): 2841-2844.

Luo, Y., J. Hurwitz, and J. Massague. 1995. Cell cycle inhibition mediated by functionally independent CDK and PCNA inhibitory domains in p21 ${ }^{C I P 1}$. Nature 375: 159-161.

Matsuoka, S., M.C. Edwards, C. Bai, S. Parker, P. Zhang, A. Baldini, J.W. Harper and S.J. Elledge. 1995. p5 $7^{\text {Kip2 }}$, a structurally distinct member of the p21CIP1 CDK inhibitor family, is a candidate tumor suppressor gene. Genes \& Dev. 9: 650-662.

Michieli, P., M. Chedid, D. Lin, J.H. Pierce, W.E. Mercer, and D. Givol. 1994. Induction of WAF1/CIP1 by a p53-independent pathway. Cancer Res. 54: 3391-3395.

Ming, F.K., J. Zhang, L. Cheng, D.N. Shapiro, and A. Winoto. 1995. Identification of human and mouse $\mathrm{p} 19$, a novel CDK4 and CDK6 inhibitor with homology to pl6 $6^{\text {ink4 }}$. Mol. Cell. Biol. 15: 2682-2688.

Missero, C., E. Calautti, R. Eckner, J. Chin, L.H. Tsai, D.M. Livingston, and G.P. Dotto. 1995. Involvement of the cellcycle inhibitor Cip1/WAF1 and the E1A-associated p300 protein in terminal differentiation. Proc. Natl. Acad. Sci. 92: 5451-5455.

Morgan, D.O. 1995. Principles of CDK regulation. Nature 374: 131-134.

Nishida, N., Y. Fukuda, T. Komeda, R. Kita, T. Sando, M. Furukawa, M. Amenomori, I. Shibagaki, K. Nakao, M. Ikenaga, and K. Ishizaki. 1994. Amplification and overexpression of the cyclin D1 gene in aggressive human hepatocellular carcinoma. Cancer Res. 54: 3107-3110.

Nobori, T., K. Miura, D. Wu, A. Lois, K. Takabayshi, and D. Carson. 1994. Deletions of the cyclin-dependent kinase-4 inhibitor gene in multiple human cancers. Nature 368: 753756.

Noda, A., Y. Ning, S.F. Venable, O.M. Pereira-Smith, and J.R. Smith.1994. Cloning of senescent cell-derived inhibitor of DNA synthesis using an expression screen. Exp. Cell. Res. 211: 90-98.

Noguchi, S., Y. Ohba, and T. Oka. 1991. Influence of epidermal growth factor on liver regeneration after partial hepatectomy in mice. $J$. Endocrinol. 128: 425-431.

Parker, S.B., G. Eichele, P. Zhang, A. Rawls, A.T. Sands, A. Bradley, E.N. Olson, J.W. Harper, and S.J. Elledge. 1995. p53independent expression of $\mathrm{p} 21^{\text {Cip1 }}$ in muscle and other terminally differentiating cells. Science 267: 1024-1027.

Polyak, K., M.-H. Lee, H. Erdjument-Bromage, A. Koff, J.M. Roberts, P. Tempst and J. Massague. 1994. Cloning of $\mathrm{p} 27^{\mathrm{Kip} 1}$, a cyclin-dependent kinase inhibitor and a potential mediator of extracellular antimitogenic signals. Cell 78: 59-66.

Sandgren, E.P., R.D. Palmiter, J.L. Heckel, C.C. Daugherty, R.L. Brinster, and J.L. Degen. 1991. Complete hepatic regeneration after somatic deletion of an albumin-plasminogen activator transgene. Cell 66: 245-256.

Segal, S., B. Shiomo, A. Fiorino, and L. Reid. 1992. The liver as a stem cell lineage system. Am. J. Physiol. 263: 139-148.

Serrano, M., G. Hannon, and D. Beach. 1993. A new regulatory 
Wu et al.

motif in cell cycle control causing specific inhibition of cyclin D/CDK4. Nature 366: 704-707.

Shaw, P., R. Bovey, S. Tardy, R. Sahli, B. Sordat, and J. Costa. 1992. Induction of apoptosis by wild-type p53 in a human colon tumor-derived cell line. Proc. Natl. Acad. Sci. 89: 4495-4499.

Sherr, C.J. 1994. G1 phase progression: Cycling on cue. Cell 79: 551-555.

Sherr, C.J. and J.M. Roberts. 1995. Inhibitors of mammalian $G_{1}$ cyclin-dependent kinases. Genes \& Dev. 9: 1149-1163.

Shiohara, M., W.S. EI-Deiry, M. Wada, T. Nakamaki, S. Takeuchi, R. Yang, D.L. Chen, B. Vogelstein, and H.P. Koeffler. 1994. Absence of WAF1 mutations in a variety of human malignancies. Blood 84: 3781-3784.

Sicinski, P., J.L. Donaher, S.B. Parker, T. Li, A. Fazeli, H. Gardner, S.Z. Haslam, R.T. Bronson, S.J. Elledge, and R.A. Weinberg. 1995. Cyclin Dl provides a link between development and oncogenesis in the retina and breast. Cell 82: 621-630.

Solomon, M.J. 1994. The function(s) of CAK, the p34cdc2-activating kinase. Trends Biochem. Sci. 19(11): 496-500.

Steinman, R.A., B. Hoffman, A. Iro, C. Guillouf, D.A. Liebermann, and M.E. El-houseini. 1994. Induction of p21 (WAF1/ CIP1) during differentiation. Oncogene 9: 3389-3396.

Symonds, H.S., S.A. McCarthy, J. Chen, J.M. Pipas, and T. Van Dyke. 1993. Use of transgenic mice reveals cell-specific transformation by a simian virus $40 \mathrm{~T}$-antigen amino-terminal mutant. Mol. Cell. Biol. 13: 3255-3265.

Symonds, H., L. Krall, L. Remington, M. Saenz-Robles, S. Lowe, T. Jacks, and T. Van Dyke. 1994. p53-Dependent apoptosis supresses tumor growth and progression in vivo. Cell 78: 703-711.

Toyoshima, H. and T. Hunter. 1994. p27, a novel inhibitor of G1 cyclin-Cdk protein kinase activity is related to p21. Cell 78: $1-20$.

Vassy, J. and M. Kraemer. 1993. Fetal and postnatal growth. In Molecular and cell biology of the liver (ed. A.V. LeBouton), pp. 265-306. CRC Press Inc., Boca Raton, FL.

Waga, S., G.J. Hannon, D. Beach, and B. Stillman.1994. The p21 inhibitor of cyclin-dependent kinases controls DNA replication by interaction with PCNA. Nature 369: 574-578.

Xiong, Y., G.J. Hannon, H. Zhang, D. Casso, R. Kobayashi, and D. Beach. 1993a. p21 is a universal inhibitor of cyclin kinases. Nature 366: 701-704.

Xiong, Y., H. Zhang, and D. Beach. 1993b. Subunit rearrangement of cyclin-dependent kinases is associated with cellular transformation. Genes \& Dev. 7: 1572-1583.

Yan, C., R.H. Costa, J.E. Darnell, J.D. Chen, and T.A. Van Dyke. 1990. Distinct positive and negative elements control the limited hepatocyte and choroid plexus expression of transthyretin in transgenic mice. EMBO J. 9: 869-878.

Yonish-Rouach, E., D. Resnitzky, J. Lotem, L. Sachs, A. Kimchi, and M. Oren. 1991. Wild-type p53 induces apoptosis of myeloid leukaemic cells that is inhibited by interleukin-6. $\mathrm{Na}$ ture 352: 345-340.

Zhang, H., Y. Xiong, and D. Beach. 1993. Proliferating cell nuclear antigen and $\mathrm{p} 21$ are components of multiple cell cycle kinase complexes. Mol. Biol. Cell 4: 897-906.

Zhang, H., G. Hannon, and D. Beach. 1994. p21-containing cyclin kinases exist in both active and inactive states. Genes \& Dev. 8: 1750-1758. 


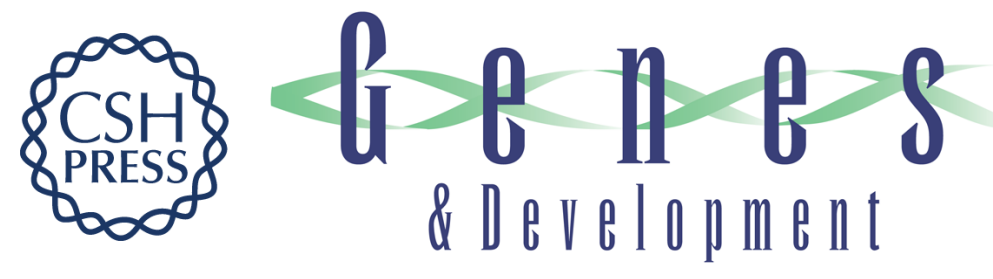

\section{Targeted in vivo expression of the cyclin-dependent kinase inhibitor p21 halts hepatocyte cell-cycle progression, postnatal liver development and regeneration.}

$\mathrm{H}$ Wu, M Wade, L Krall, et al.

Genes Dev. 1996, 10:

Access the most recent version at doi:10.1101/gad.10.3.245

References This article cites 73 articles, 35 of which can be accessed free at: http://genesdev.cshlp.org/content/10/3/245.full.html\#ref-list-1

License

Email Alerting Service

Receive free email alerts when new articles cite this article - sign up in the box at the top right corner of the article or click here.

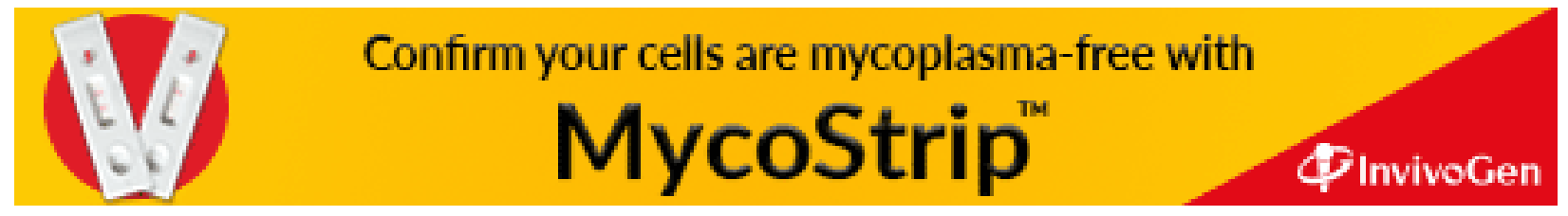

